\title{
SERGIO RACHMAN
}

\section{A interface entre psiquiatria e literatura na obra de Lima Barreto}

Dissertação apresentada à Faculdade de Medicina da Universidade de São Paulo para obtenção do título de Mestre em Ciências

Área de concentração: Psiquiatria

Orientador: Prof. Dr. Francisco Lotufo Neto

São Paulo 
Dados Internacionais de Catalogação na Publicação (CIP)

Preparada pela Biblioteca da

Faculdade de Medicina da Universidade de São Paulo

Creprodução autorizada pelo autor

Rachman, Sergio

A interface entre psiquiatria e literatura na obra de Lima Barreto / Sergio Rachman. -- São Paulo, 2010.

Dissertação(mestrado)--Faculdade de Medicina da Universidade de São Paulo.

Departamento de Psiquiatria.

Área de concentração: Psiquiatria.

Orientador: Francisco Lotufo Neto.

Descritores: 1.Psiquiatria/história 2.Medicina na Literatura 3.Linguística/estatística \& dados numéricos

USP/FM/SBD-070/10 
Dedico esta dissertação a duas memórias, a de meu pai e a do escritor que é tema das páginas que seguem. Tenho certeza de que meu pai ficaria muito feliz por ver este trabalho concluido. Quanto ao escritor, não estou tão convicto dîsso. Peço-lhe desculpas se em algum momento incorri em alguma forma de reducionismo e esclareço que não há aqui nenhuma intenção de se fazer critica literária, área da qual o pesquisador não nossui analauer dominio. 
Agradecimentos

Ao Prof. Dr. Francisco Lotufo Neto, orientador deste trabalho e sem o qual ele não teria sequer começado. Sou grato por sua paciência, cordialidade, generosidade e ousadia, que permitem o estabelecimento de novos e fundamentais ares dentro da ciência psiquiátrica;

Aos Profs. Drs. José Paulo Fiks, Monica Levit Zilberman e Danilo Antonio Baltieri, pelas valiosas contribuições apresentadas no exame de qualificação;

Ao Prof. Dr. Alexandre Saadeh, grande incentivador de minha carreira acadêmica e profissional;

Ao Prof. Dr. Sergio Paulo Rigonatti, apreciador de ópera e artes em geral, que não escondeu seu entusiasmo pelo tema deste trabalho;

Ao Prof. Dr. Tony Berber Sardinha, pessoa de incrível simpatia e disponibilidade, que me apresentou ao Wordsmith Tools;

Ao meu grande amigo Marcello Berland, que contribuiu com a execução dos gráficos. Sem sua ajuda, estaria até o fim dos tempos tentando aprender a mexer no Excel;

Ao Rafael Izbicki, jovem estatístico que, com sua incrível solicitude, me socorreu em um momento de desagregação numérica, quadro psicopatológico dos mais temíveis e que ainda não foi validado nos sistemas CID e DSM;

Ao Renato Akerman, que me escutou pacientemente todas as semanas nos últimos anos, e me ajudou a dar mais vazão ao meu ld e a dissolver o meu Superego;

À Sra. Eliza Sumie Sogabe Fukushima, cuja dedicação integral à pósgraduação do IPq nos ajuda a não esquecer dos trâmites e dos prazos;

Ao Porgy, que mesmo sem entender nada do que eu estava fazendo, acompanhou-me noites a fio e me deu o prazer de sua agradabilíssima companhia, mesmo sem receber biscoitos em troca;

A todos os meus amigos, que sempre me apoiaram e que não citarei individualmente para não cometer nenhuma omissão injusta;

À minha família, Marlene Rachman (mãe) e Luciano Rachman (irmão), que me deram os subsídios para eu ser quem sou;

À minha segunda família, Sr. Reynaldo, Sra. Rachela e Srta. Priscila Eisenstadt, que me receberam em seu seio familiar como a um rei; 
E por fim, um agradecimento especial ao amor de minha vida e que acompanhou todo o processo, torcendo e sofrendo comigo. Se essa dissertação fosse um poema, você, Paula, seria minha musa inspiradora. 
"As coisas estão longe de ser todas tão tangiveís e diziveis quanto se nos pretendería fazer crer; a maior parte dos acontecimentos é inexprimivel e ocorre num espaço em que nenhuma palavra jamais pisou. Menos suscetiveis de expressão do que qualquer outra coisa são as obras de arte - seres misteriosos cuja vida perdura, ao lado da nossa, efêmera." (Rainer Maria Rilke - carta a Franz Xaver Kappus) 


\section{SUMÁRIO}

Lista de siglas

Lista de figuras

Lista de tabelas

Lista de gráficos

RESUMO

SUMMARY

1.INTRODUÇÃO. 01

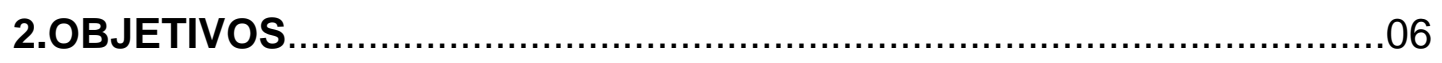

3.REVISÃO DA LITERATURA

3.1 - A psiquiatria da época de Lima Barreto...........................................

3.2 - A obra literária como fonte histórica...............................................

3.3 - Relação entre temperamento artístico e alcoolismo.........................12

3.4 - Efeitos cognitivos do uso crônico de álcool.......................................13

3.5 - Linguística como instrumento de avaliação psicopatológica..............14

3.6 - Análise psicopatológica do artista em função de sua obra................17

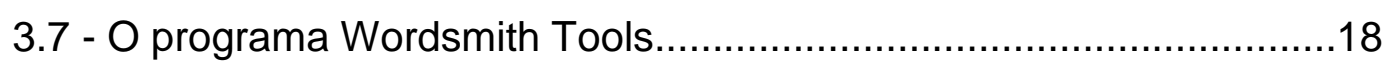

3.8 - Vida e obra de Lima Barreto..........................................................22

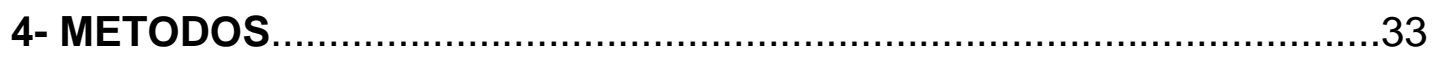

4.1- Elementos linguísticos extraídos dos corpora através do uso

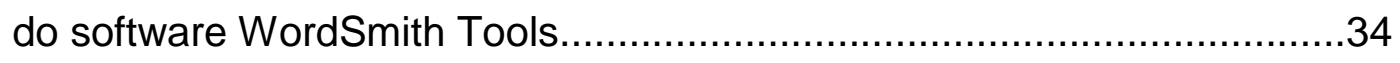

5- RESULTADOS

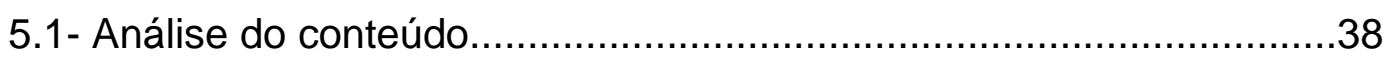


5.1.1- Evolução da representação da doença mental na obra de Lima Barreto

5.1.2- A visão de Lima Barreto sobre a Psiquiatria 61

5.1.3- O Hospício Pedro II retratado em O cemitério dos vivos. .70

5.1.4 - A visão de Lima Barreto sobre o caráter da doença mental...........75

5.1.5- Aspectos psicológicos de Lima Barreto presentes no

Diário Íntimo e em O cemitério dos vivos. 80

5.2- Análise da forma: Resultados das análises linguísticas com o uso do Wordsmith Tools. .84

6- DISCUSSÃO

6.1 - Lima Barreto, psiquiatria e doença mental.....................................92

6.2- As trajetórias dos protagonistas barretianos..................................100

6.3- As análises linguísticas das obras com o uso da ferramenta computacional................................................................103

7- CONCLUSÕES

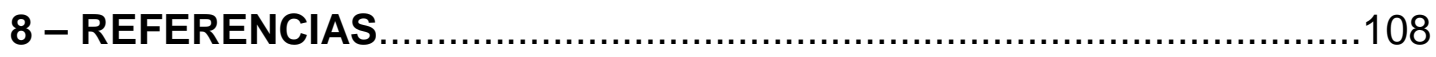




\section{LISTA DE SIGLAS}

CE Corpus de Estudo

CR Corpus de Refência

DSM-III Diagnostic and Statistical Manual of Mental Disorders- $3^{\text {rd }}$ edition HNA Hospício Nacional de Alienados

MBE Medicina Baseada em Evidências

p página

pp páginas

Unifesp Universidade Federal de São Paulo

USP Universidade de São Paulo 


\section{LISTA DE FIGURAS}

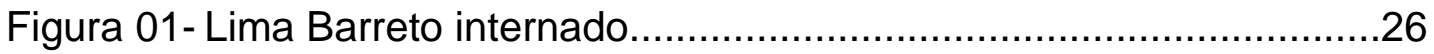

Figura 02 - Lima Barreto no auge da carreira...........................................26

Figura 03 - Esquema mostrando o processo de geração dos

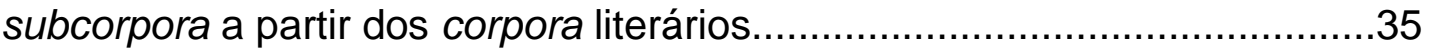




\section{LISTA DE TABELAS}

Tabela 1- Valores de types, tokens e índice type-token para

cada uma das partes das obras literárias de referência

Tabela 2- Valores de types, tokens e índice type-token para

as obras de Lima Barreto

Tabela 3- Palavras-chave, confrontando-se o corpus de estudo

com o corpus de referência.

Tabela 4- Ocorrências da palavra mania no corpus de estudo......................90

Tabela 5- Ocorrências da palavra mania no corpus de referência.

Tabela 6- Síntese dos achados da ocorrência da palavra mania

no corpus de estudo (CE) e no corpus de referência (CR). 


\section{LISTA DE GRÁFICOS}

Gráfico 1- Valores evolutivos de type e token para as obras analisadas.

Gráfico 2- Valores evolutivos de type e token para

as obras de Lima Barreto. 


\section{RESUMO}

Rachman S. A interface entre psiquiatria e literatura na obra de Lima Barreto [dissertação]. São Paulo: Faculdade de Medicina, Universidade de São Paulo; 2010. 117p

INTRODUÇÃO: As humanidades médicas têm sido cada vez mais valorizadas mundialmente. No entanto, são poucos os estudos psiquiátricos nessa área no Brasil. A obra de Lima Barreto (1881-1922) reveste-se de importância para o psiquiatra pelo fato de este escritor ter tido grande contato com o meio psiquiátrico de sua época, em virtude da doença mental de seu pai e de seu quadro de alcoolismo, que motivou duas internações no Hospício Nacional de Alienados do Rio de Janeiro. Neste trabalho, procuramos relacionar a obra de Lima Barreto ao contexto histórico da psiquiatria e à sua biografia, testando ainda a hipótese de que o autor tenha apresentado declínio cognitivo expresso na elaboração de sua última obra, em virtude do alcoolismo. MÉTODOS: A obra do autor foi pesquisada, sendo analisadas as representações de doença mental. Como referencial teórico, utilizou-se os conceitos de carnavalização e de cronotopo de Mikhail Bakhtin. Foi usado, ainda, um software (WordSmith tools 3.0) para encontrar variáveis linguísticas que pudessem ter relação com declínio cognitivo do autor. RESULTADOS: Nas primeiras obras, há tendência para caracterizar a doença mental de forma idealizada ou caricatural; nas últimas, de forma mais naturalista e objetiva. Os percursos dos personagens dos últimos romances têm tendências mais fatalistas, com menor grau de mudança psicológica dos personagens, quando comparados com os romances iniciais. Com os relatos do autor sobre sua internação, tem-se acesso a uma descrição das condições do Hospício Nacional de Alienados, de seus internos e do caráter das internações. Observou-se, também, menor diversidade lexical na última obra do autor, aferido pelo software. CONCLUSÕES: A obra de Lima Barreto é uma fonte representativa para aqueles que estudam história da psiquiatria brasileira do início do século XX e fornece elementos diversos daqueles presentes em vários estudos, principalmente ligados a ideologias críticas à psiquiatria. As diferenças nas representações da doença mental no início e no fim da obra provavelmente refletem elementos biográficos e psicológicos do autor. $\mathrm{O}$ achado de menor diversidade lexical presente na última obra pode ter relação com declínio cognitivo do autor.

Descritores: Psiquiatria/história, Medicina na Literatura, Linguística/estatística \& dados numéricos. 


\section{SUMMARY}

Rachman S. The interface between psychiatry and literature in the work of Lima Barreto [dissertation]. São Paulo: "Faculdade de Medicina, Universidade de São Paulo"; 2010. 117p

INTRODUCTION: The medical humanities have been increasingly valued worldwide. However, there are few psychiatric studies in this area in Brazil. The work of Lima Barreto (1881-1922) is important to the psychiatrist because this writer had great contact with the psychiatric medium of his time, because of his father's mental illness and because of his picture of alcoholism, which led him to two hospitalizations in the National Asylum for the Insane in Rio de Janeiro. In this paper we try to relate the work of Lima Barreto to the historical context of psychiatry and his biography, testing also the hypothesis that the author had cognitive decline expressed in the preparation of his latest book, due to alcoholism. METHODS: The author's work was investigated, and the representations of mental illness analyzed. The theoretical framework used included Mikhail Bakhtin's concepts of chronotope and carnivalization. It was also used a software (WordSmith tools 3.0) to find linguistic variables that could be related to cognitive decline of the author. RESULTS: In early works, there is a tendency to characterize mental illness in an idealized or caricatured way, and in the late ones, in a more naturalistic and objective way. The paths of the characters in later novels have more fatalistic tendencies, with lower levels of psychological change of the characters, when compared to the early novels. With the reports of the author on his admission in the psychiatric hospital, we have access to a description of condition of the National Asylum for the Insane, its internals and the character of admissions. It was also observed that there was less lexical diversity in the last work of the author, as measured by the software. CONCLUSIONS: Lima Barreto's work is a representative source for those studying the history of psychiatry of the early twentieth century and provides different elements compared to those present in several studies, mainly linked to ideologies critical to psychiatry. The differences in the representations of mental illness at the beginning and the end of the work probably reflect biographical and psychological elements of the author. The finding of lower lexical diversity present in the latest work may be related to cognitive decline of the author.

Descriptors: Psychiatry/history, Medicine in literature, Linguistics/statistics \& numerical data. 


\section{1- INTRODUÇÃO}

Há um debate contemporâneo a respeito do papel que as artes, e especialmente a literatura, teriam na prática clínica e psiquiátrica em um ambiente científico em que aumenta a influência da medicina baseada em evidências (MBE) (Geddes, 1998).

Beveridge (2003) enumera várias razões pelas quais a leitura de textos literários é importante para os psiquiatras. Ela daria: possibilidade de explorar as vidas e os mundos internos de uma grande variedade de personagens das estórias, acesso a uma perspectiva existencial e emocional que um modelo biocientífico puro não oferece, ajuda na criação de capacidade de empatia, abordagens éticas de questões que os psiquiatras normalmente enfrentam, elementos estéticos que normalmente estão presentes nos discursos de pacientes e possibilidade de humanização de um contato com o paciente que muitas vezes é excessivamente técnico.

No entanto, não existem apenas argumentos favoráveis à incorporação da literatura na prática psiquiátrica, pois não há construções inocentes de significados a partir de obras literárias. Claramente, a ficção pode levar o leitor a desenvolver compreensões errôneas acerca de um assunto. Existem riscos quando são entendidos como fonte de conhecimento textos em que a narrativa flui facilmente com persuasão, de modo que o processo de busca da verdade é deixado de lado e perdido no fluxo dos acontecimentos envolvendo os personagens da ficção (Roberts, 
2000). Outra autora (Gersie, 1997) também alerta para esse problema e afirma que a tendência do escritor de atribuir seus sofrimentos a certas experiências pode dar origem a narrativas que contribuam para a valorização de uma cultura de vitimização. Do mesmo modo, a tendência que os leitores têm de aceitar interpretações falsas como sendo pertinentes se elas se adequarem às suas expectativas ou preferências também é obstáculo importante para a utilização de narrativas ficcionais como fonte de conhecimento. Beveridge (2003), por fim, argumenta que o hábito de ler ficção não garante a um médico que ele desenvolverá maior empatia por seus pacientes, já que a leitura em si é um hábito solitário e que pode estar associado a motivações egoístas de expansão dos horizontes intelectuais, sem que isso se traduza em maior sensibilidade em relação a outras pessoas.

De qualquer modo, o conhecimento médico baseado nas artes tem sido valorizado desde a década de 1990 , tendo sido criados jornais de humanidades médicas no Reino Unido, na Europa e ao longo da costa atlântica nos Estados Unidos. Também não é mais incomum encontrar colunas de poemas incluídas nos principais jornais científicos e há centros de humanidades médicas e cursos sobre esse tema na graduação em escolas de medicina nos Estados Unidos (Oyebode, 2002).

No Brasil, existem também iniciativas em algumas das mais importantes faculdades de medicina para valorizar disciplinas que contemplem as humanidades. Na Universidade Federal de São Paulo, Unifesp, funciona um grupo denominado Laboratório de Humanidades, a 
cargo do professor Dante Marcello Gallian, com o objetivo de discutir textos clássicos de filosofia e literatura. ${ }^{1} \mathrm{Na}$ Faculdade de Medicina da USP, com a implementação de uma reforma curricular em 1998, passaram a ser ministradas disciplinas com o objetivo de propiciar conteúdo humanístico e social à formação do médico².

No entanto, ao mesmo tempo em que a interface entre as artes e a medicina em geral passou a ser mais valorizada, a psiquiatria adotou caminho contrário, havendo uma guinada em direção a uma ciência rigorosa como base para conhecimento estável e o ensino da prática em psiquiatria (Green, 2008). É nesse contexto que foi elaborado o DSM-III, com o objetivo maior de criar um sistema compreensivo para avaliar e diagnosticar os pacientes psiquiátricos, que fosse mais confiável e que tivesse mais validade e consistência para ser usado em âmbito internacional. Como consequência, as formas de ensino e de prática psiquiátricas se tornaram mais mecânicas e reducionistas, com desvalorização dos aspectos singulares de cada indivíduo que adoece mentalmente (Zoppe, 2007). Neste sentido, a psiquiatria estaria de forma surpreendente se afastando do restante da medicina.

Alguns críticos em relação a essa tendência na psiquiatria têm tentado reintroduzir as artes, e a literatura em particular, como aspectos significativos na prática e na formação psiquiátrica. Surgem, então, algumas questões de suma importância e que não foram ainda respondidas: Qual é o

\footnotetext{
${ }^{1}$ Informação disponível no sítio http://labhum.blogspot.com, consultado em 31/12/2009.

2 Informação disponível no sítio http://www.fm.usp.br/cedem/hum, consultado em 31/12/2009.
} 
papel que as artes teriam na psiquiatria? A psiquiatria é uma ciência pragmático-empírica em que interpretações subjetivas não teriam vez ou ela teria um caráter subjetivo cujas bases poderiam se alimentar de uma interface produtiva com as artes? (Green, 2008).

Como se vê, essa é uma questão complexa e que vem ganhando cada vez mais importância para aqueles que trabalham em psiquiatria. No entanto, é um tema abordado em poucos estudos no Brasil. É por essa razão que uma dissertação acadêmica sobre a interface entre psiquiatria e literatura é tão importante.

A escolha do autor estudado se justifica por sua biografia e obra. Lima Barreto viveu a maior parte de sua vida em contato íntimo com a psiquiatria e a doença mental, seja por causa de seu pai que sofria de quadro delirante (Barbosa, 2003), seja por seu próprio histórico de alcoolismo e internações psiquiátricas, que foram tão bem retratadas em seu romance inacabado O Cemitério dos Vivos. Outras obras suas, Recordações do Escrivão Isaías Caminha, Triste fim de Policarpo Quaresma e Clara dos Anjos, também trazem representações da doença mental, que podem ser relacionadas ao momento em que os romances foram escritos.

Analisando-se o conteúdo literário de 0 cemitério dos vivos, encontram-se várias referências à psiquiatria da época e descrições de doentes mentais com os quais conviveu no hospital psiquiátrico. Assim, temse um importante relato literário, com base nas experiências do autor, da história da psiquiatria. Outro aspecto importante a ser destacado são as 
referências autobiográficas que permeiam grande parte das narrativas de Lima Barreto, o que permite uma melhor compreensão de aspectos psicológicos de um autor importante na literatura brasileira e do sofrimento mental do qual padeceu.

Quanto à forma das narrativas, o seu estudo permite que se comparem diferentes momentos da obra do autor, em busca de mudanças no modo de escrever. Sabendo-se os anos em que foram escritos os livros, e correlacionando os mesmos com o momento de vida e de doença do autor, pode-se testar a hipótese de que o alcoolismo tenha interferido na cognição do mesmo e, consequentemente, na obra com o passar do tempo.

Dessa forma, esta dissertação tem como objetivo a busca do contexto histórico-psiquiátrico em que estão inseridas as obras de Lima Barreto, além dos aspectos cognitivos e biográficos do autor, que interferiram na representação da doença mental nas obras literárias. 


\section{2- OBJETIVOS}

Tomando como ponto de partida a obra de lima Barreto:

1- Correlacioná-la com o momento histórico da psiquiatria e apresentá-la como possível fonte de pesquisa em história da psiquiatria;

2- Analisar a evolução da representação da doença mental, correlacionandoa com elementos biográficos do autor;

3- Comparar alguns parâmetros linguísticos de diferentes romances e correlacioná-los a possíveis aspectos cognitivos na ocasião em que foram escritos. 


\section{3- REVISÃO DA LITERATURA}

\section{1- A psiquiatria da época de Lima Barreto}

Até a primeira metade do século XIX, os doentes mentais no Brasil não recebiam tratamento em instituições especificamente concebidas para esse fim. No Rio de Janeiro, a Santa Casa de Misericórdia cumpria até então o papel de acolher alienados, mas as condições precárias enfrentadas pelos internos motivaram reações por parte da sociedade, que culminaram na criação do primeiro hospital psiquiátrico do Brasil, o Hospício Pedro II (futuramente renomeado Hospício Nacional de Alienados [HNA], após a Proclamação da República), em 1852 (Paim, 1991). O Pedro II foi construído de acordo com o molde francês, inclusive em seus estatutos de funcionamento. Segundo essa concepção, idealizada por Pinel e Esquirol, o hospital psiquiátrico cumpriria sua função terapêutica através do trabalho dos médicos, que seriam ajudados pelos enfermeiros e pela estrutura física adequada do manicômio (Pessotti, 1996).

A abordagem preconizada para os doentes mentais pela escola francesa era o tratamento moral, termo que foi criado por Pinel em 1801. O doente seria, de acordo com esse método, retirado de seu convívio social para se afastar do excesso de estímulos emocionais de sua vida cotidiana. Experimentando uma realidade sem excessos, com rotina regrada e sujeitos à ordem e à disciplina impostos pelo alienista e pelos limites do manicômio, 
os internos teriam as condições necessárias para a recuperação (Short, 1997).

Em seu Tratado médico-filosófico sobre a alienação mental ou a mania, publicado pela primeira vez em 1800, Pinel divide a mania em cinco categorias: melancolia, mania sem delírio, mania com delírio, demência e idiotismo. $\mathrm{O}$ termo isolado mania se referia às chamadas loucuras gerais ou furiosas.

Segundo Oda e Dalgalarrondo (2007), o discurso médico no Brasil na época da criação dos primeiros hospitais psiquiátricos estava impregnado com o ideal pineliano. A filiação do HNA a este modelo, no entanto, teria sido apenas nominal, não chegando a ocorrer de fato. E assim como em inúmeras outras instituições para tratamento de alienados espalhadas pelo mundo, vários problemas surgiram nesse manicômio, sendo o mais conhecido deles a superlotação, que fez com que, em 1862, o provedor da Santa Casa, que até então administrava o HNA, proibisse novas admissões de internos. A mesma situação foi observada em várias outras capitais das Províncias.

Segundo Paim (1991), o fator decisivo para o surgimento de uma psiquiatria com características nacionais foi o aparecimento de Juliano Moreira, especialmente a partir da época em que assumiu a direção do HNA, em 1903, permanecendo em tal função até 1930. Esse médico foi responsável pela introdução no meio psiquiátrico brasileiro de ideias da escola alemã, representada por Emil Kraepelin (1826 - 1926). 
Os diagnósticos mais comuns entre os internos do HNA em 1875 eram demência, mania, monomania, lipemania, epilepsia, alcoolismo, imbecilidade, histeria e paralisia geral, sendo que grande parte dos internos eram indigentes (Rey apud Postel e Quétel, 1987). Em relatório enviado por Juliano Moreira ao Ministro da Justiça do Brasil em 1922, aquele afirma que "o alcoolismo conservou o primeiro lugar entre as causas predominantes de novas internações do Hospício Nacional."

\section{2- A obra literária como fonte histórica}

Pretende-se, nesta dissertação, tomar a obra de Lima Barreto como fonte histórica da psiquiatria do início do século XX. Existem alguns historiadores que endossam essa conduta.

Em artigo de 2006, Pesavento, professora aposentada de história da UFRGS, contrapõe as narrativas históricas às literárias, e conclui que estas também são importante fonte de conhecimento para a compreensão de um determinado período histórico. Ela afirma: "A literatura é, pois, uma fonte para o historiador, mas privilegiada, porque the dará acesso especial ao imaginário, permitindo-Ihe enxergar traços e pistas que outras fontes não lhe dariam." Mais adiante, ela declara que não é necessário, para que um texto literário tenha valor como documento histórico, que seja demonstrada a real existência de todos os fatos ou personagens nele contidos: "A verdade da ficção literária não está, pois, em revelar a existência real de personagens e fatos narrados, mas em possibilitar a leitura das questões em jogo numa 
temporalidade dada. (...) Admitimos que a literatura é fonte de si mesma enquanto escrita de uma sensibilidade, enquanto registro, no tempo, das razões e sensibilidades dos homens em um certo momento da história". E conclui: "A verdade da ficção literária não está, pois, em revelar a existência real de personagens e fatos narrados, mas em possibilitar a leitura das questões em jogo numa temporalidade dada."

Guimarães (2007), em trabalho baseado em sua tese de doutorado, aplica a ideia de avaliar um momento histórico através do estudo de obra literária ao examinar como o território amazônico era visto na sociedade brasileira da Primeira República. Para isso, utiliza um conjunto de escritos de Euclides da Cunha como "exemplar dos discursos circulantes à época sobre a floresta." Analogamente, pode-se, então, considerar obras literárias que abordem a psiquiatria como documentos que ilustram o modo como a mesma era vista ou compreendida na época em que a obra foi escrita.

Em artigo de 2007, Beveridge mostra vários aspectos das doenças mentais que foram retratados na obra de Dostoievski e sugere que este autor forneceu um quadro complexo e sofisticado da doença mental, que tem relevância no modo como os médicos contemporâneos concebem a mesma. Em sua obra, "assim como incontáveis casos de insanidade, há descrições de alcoolismo, epilepsia, idiotia, abuso sexual, suicídio, jogo patológico e transtorno de personalidade." Segundo o autor, Dostoievski tinha interesse em psicologia e leu escritores contemporâneos que versavam sobre o assunto. Dessa forma, em vários momentos de sua obra o leitor tem acesso a teorias psicológicas da época e ao modo como a loucura era vista. 
Outro aspecto enfatizado por Beveridge é a importância de se considerar a atitude de Dostoievski com relação à ciência, que rejeitava o materialismo puro e não via na mesma a possibilidade de descoberta de todos os enigmas humanos, para que se possa compreender a sua visão da loucura, não reducionista.

Uma obra bastante conhecida nos meios acadêmicos psiquiátricos brasileiros é A psiquiatria de Machado de Assis, escrita por José Leme Lopes (1974). Nesse livro, o autor faz uma análise de vários personagens machadianos em sua relação com a psiquiatria e mostra que o leitor encontra através dos mesmos vários subsídios à compreensão do adoecer psíquico.

No caso específico da obra de Lima Barreto, sua relevância histórica é apontada por Fábio Lucas, no prefácio de uma edição de 2004 de 0 cemitério dos vivos:

O simples fator autobiográfico da publicação dá-lhe cunho historiográfico, já que as memórias, diários e confissões não passam de textos ancilares da historiografia, mormente agora, quando se busca a história das mentalidades. Na mesma linha, os romances de Lima Barreto contribuem para o desenho de época da cidade do Rio de Janeiro, num dos melhores painéis da aparência física e moral da cidade.

Teixeira (2001), comentando O triste fim de Policarpo Quaresma, afirma: "A sondagem do desequilíbrio de Quaresma permitiu [a Lima Barreto] 
construir com traços fortes as alucinações, os desejos, e as manias que caracterizavam a noção de loucura conforme os padrões de seu tempo." Percebe-se, assim, como a obra de Lima Barreto pode ter importância para o estudo das representações da doença mental durante o tempo em que viveu o escritor.

\section{3- Relação entre temperamento artístico e alcoolismo}

O quadro de alcoolismo que Lima Barreto sofreu é bastante descrito em artistas, por vários estudiosos.

Post (1996) encontrou alta prevalência de alcoolismo e transtornos afetivos em uma amostra de 100 escritores americanos e britânicos. O mesmo autor, em 1994, ao investigar a vida de 291 homens mundialmente famosos nas artes, ciências, política e pensamento, havia formulado uma relação causal entre tendências à depressão e alcoolismo e alguns tipos de criatividade. Ludwig (1994), entrevistando 59 escritoras e 59 pessoas de um grupo controle, chegou à conclusão de que as escritoras eram mais propensas a sofrer de distúrbios do humor, abuso de drogas, ataques de pânico, ansiedade generalizada e transtornos alimentares, o que, de acordo com o autor, sugere uma correlação direta entre criatividade e doença mental.

As relações entre produção artística e alcoolismo são bastante complexas. Davis (1986) e Lester (1991) relatam a mortalidade prematura em autores americanos proeminentes por alcoolismo. O segundo autor 
ressalta ainda os altos índices de suicídio nessa população. Ambos expõem os custos sociais decorrentes da perda precoce desses indivíduos. Day e Smith (2002) analisam as relações entre literatura e alcoolismo e apontam para o caso de F. Scott Fitzgerald, em que o abuso de álcool levou a um declínio tanto na saúde quanto na produção escrita. Ludwig, em estudo publicado em 1990, baseado na análise das biografias de 34 escritores, artistas e compositores famosos do século XX que eram abusadores de álcool, chegou à conclusão de que essa substância comprometeu a produtividade de suas carreiras, principalmente na fase final, em 75 por cento da amostra.

Por outro lado, Brunke et al (1992), analisaram as produções escritas de 11 indivíduos sóbrios e sob efeito do álcool, encontrando maior quantidade de escritos criativos após a ingesta de álcool.

Dessa forma, ainda é motivo de debate o quanto 0 ato de beber poderia ou não favorecer a criatividade artística, em certos momentos. No entanto, é consenso que o uso abusivo e prolongado de álcool leva a declínio cognitivo, como mostrado a seguir.

\section{4- Efeitos cognitivos do uso crônico de álcool}

Baltieri, em dissertação de mestrado de 2002, afirma que "prejuizos cognitivos são freqüentemente observados em pacientes dependentes crônicos de álcool etílico. Múltiplas funções cognitivas são afetadas pelo consumo crônico dessa substância, como capacidade de planejamento, 
pensamento abstrato e crítica. Muito semelhante à Demência de Alzheimer, a síndrome demencial alcoólica manifesta-se por prejuízo progressivo da memória, da atenção e da orientação."

Sullivan et al (2000) constataram que o tempo de consumo de álcool se relaciona a prejuízos graves no desempenho de indivíduos em testes psicológicos, principalmente com relação às memórias verbal e não-verbal. Vieira el al (2007) confirmaram esses achados em estudo de caso clínico de um indivíduo que possuía histórico de 26 anos de uso pesado de bebidas etílicas. Estes mesmos autores citam estudo de Riege, de 1987, em que foi constatado que indivíduos alcoolistas apresentam menor comprometimento relativo para execução de tarefas simples; à medida que se eleva a complexidade das tarefas, aumentam os prejuízos aferidos, inclusive em memória verbal, para palavras.

Cunha e Novaes (2004) afirmam: "Indivíduos que fazem uso crônico do álcool, porém assintomáticos do ponto de vista neurológico, podem apresentar disfunções em áreas pré-frontais do cérebro, implicando em déficits neuropsicológicos em fluência verbal (linguagem expressiva) e no controle inibitório. Tais problemas parecem estar relacionados a alterações nas funções executivas e também na memória operativa."

\section{5- Linguística como instrumento de avaliação psicopatológica}

A linguística é definida como a disciplina que estuda cientificamente a linguagem (Martelotta, 2008). Para Critchley (1994), "linguagem é o 
resultado de atividade neural complexa que permite a expressão ou percepção de estados emocionais e psicológicos através de sinais auditivos, gráficos ou gestuais, usando funções sensitivas ou motoras não especializadas inicialmente para esse fim."

O modo como a linguagem é estruturada reflete o pensamento de quem a produz. Dessa forma, seu estudo é muito importante na psiquiatria, pois permite que se tenha acesso ao estado mental dos indivíduos, bem como a outras esferas psíquicas e cognitivas. Dentre as fontes de material linguístico, podem-se citar as produções verbais faladas e escritas, incluindo-se nessa última categoria as obras literárias.

Andreasen (1976) descreve, por exemplo, algumas diferenças entre os discursos falados de pacientes com quadro clínico de depressão e mania, utilizando método de linguística quantitativa. Os primeiros usaram mais verbos de ligação, ao passo que os pacientes com mania usaram mais verbos de ação e adjetivos, o que aponta para uma linguagem mais "colorida". Associado ao quadro de depressão, pôde-se constatar a maior incidência de advérbios, enquanto na mania ocorreram mais substantivos, principalmente os concretos. Os pacientes deprimidos também tenderam a usar mais verbos no pretérito e a mostrar uma maior preocupação consigo mesmos, o que é evidenciado pelo maior uso de pronomes na primeira pessoa. Os deprimidos também tiveram os índices razão verbo-adjetivo (número de verbos dividido pelo número de adjetivos), razão verbosubstantivo e razão verbo de ligação-verbo de ação maiores que os maníacos. 
Estudos de linguística aplicada à psiquiatria são raros na literatura científica. De acordo com Thomas et al (1994), a linguagem constitui a principal ferramenta investigativa e terapêutica na prática dos psiquiatras, mas o estudo da linguística ainda não faz parte da educação desses profissionais. Para compreender importantes desenvolvimentos da ciência cognitiva, alguma familiaridade com a linguística é essencial.

Existem duas vertentes fundamentais na linguística: a chomskyana (fundada por Noam Chomsky no final dos anos de 1950 e estruturada em teorias racionalistas) e a linguística de corpus, que ganhou força na década de 1960, com o desenvolvimento dos computadores e de softwares especialmente aplicados à área. A linguística de corpus contrapõe-se à chomskyana por ser empirista, demonstrando as alterações de linguagem por meio de tratamento estatístico das variações linguísticas encontradas nos corpora. Um corpus é definido como "um conjunto de dados linguísticos (pertencentes ao uso oral ou escrito da língua, ou ambos), sistematizados segundo determinados critérios, suficientemente extensos em amplitude e profundidade, de maneira que sejam representativos da totalidade do uso linguístico ou de algum de seus âmbitos, dispostos de tal modo que possam ser processados por computador, com a finalidade de propiciar resultados vários e úteis para a descrição e análise" (Sardinha TB, 2004). Dessa forma, quando um determinado escritor produz obras literárias, ele coloca à disposição do pesquisador em linguística empirista vários corpora passíveis de análise quantitativa, em função do interesse da pesquisa a ser conduzida. 


\section{6- Análise psicopatológica do artista em função de sua obra}

Até os dias atuais, existem poucos registros no banco de dados do Medline de estudos de linguística aplicados à psiquiatria com base em corpora extraídos de obras literárias. Esse tipo de estudo permite fazer uma análise da biografia do autor em função das propriedades linguísticas de suas obras, trazendo informações muito importantes em psicopatologia aplicada, além de apresentar algumas vantagens em relação à análise de produções escritas ou verbais de indivíduos submetidos a avaliação médica: as obras literárias são escritas voluntariamente e presumivelmente vêm naturalmente ao sujeito, o escritor não tenta compensar supostas deficiências intelectuais porque não se sente avaliado e a disponibilidade de materiais literários anteriores e posteriores ao desenvolvimento da doença mental traz a oportunidade de comparações dentro do mesmo indivíduo.

$\mathrm{Na}$ presente dissertação, foi realizada uma busca nas bases Pubmed e Psyclnfo usando os termos "linguistics analysis", "literature", "corpus linguistics" e "creative writing", sendo encontrado o estudo de Garrard et al (2005), que analisou obras literárias usando a linguística de corpus. Não foram encontrados outros trabalhos que tenham usado metodologia semelhante. Esses autores fizeram uma análise de três romances da escritora britânica Iris Mordoch: Under the net, The sea, the sea e Jackson's dilemma, citados em ordem cronológica na qual foram escritos. Essa escritora começou a apresentar sintomas de Demência de Alzheimer na época em que estava concluindo a última dessas obras, que de acordo com a crítica literária é bastante inferior às demais. A própria Iris 
afirmou que durante a elaboração desse romance apresentou o "branco do escritor", não conseguindo desenvolver a narrativa com a mesma fluidez. Jackson's dilemma foi publicado em 1995. Um ano depois, a escritora apresentava pontuação no Mini-exame do Estado Mental de 20/30. Em 1997, seu desempenho na mesma avaliação foi de 10/30, evidenciando déficit cognitivo rapidamente progressivo. O diagnóstico de Demência de Alzheimer foi confirmado com exame post-mortem de amostras de seu tecido cerebral.

O estudo em questão mostrou que o último livro de Iris apresentou algumas características compatíveis com empobrecimento semântico atribuído ao quadro demencial. Comparado aos dois outros livros, existe menor incremento de palavras novas com o avançar da narrativa, maior número de repetições de palavras e tendência ao uso de sentenças mais simples e curtas. As proporções de classes gramaticais usadas nos três romances não variaram substancialmente.

\section{7- O programa Wordsmith Tools}

Um dos recursos mais utilizados para a análise de textos no computador, em Windows, é o software Wordsmith Tools, que foi desenvolvido por Mike Scott, da Universidade de Oxford. Este programa permite que os corpora sejam analisados através do uso de três ferramentas: wordlist (lista de palavras), keywords (palavras-chave) e concord (análise de concordâncias). Em seu livro Linguística de corpus 
(2004), Tony Berber Sardinha apresenta de maneira bastante didática o modo de operação do Wordsmith Tools, bem como os dados fornecidos por este. Nos próximos itens, transcrevo alguns trechos de interesse dessa obra.

\subsection{1- Wordlist}

"Propicia a criação de listas de palavras. O programa é pré-definido para produzir, a cada vez, duas listas de palavras, uma ordenada alfabeticamente e outra classificada por ordem de frequência das palavras (com a palavra mais frequente encabeçando a lista). Cada uma dessas listas é apresentada em uma janela diferente, e, juntamente com as duas janelas correspondentes à lista alfabética $(A)$ e por frequência $(F)$, o programa oferece uma terceira janela (S) na qual aparecem estatísticas relativas aos dados usados para produção das listas. Assim, para cada vez que o wordlist é chamado para fazer uma lista de palavras, três janelas são produzidas: uma contendo uma lista de palavras ordenadas por ordem alfabética, outra com uma lista classificada pela frequência das palavras, e uma terceira janela com estatísticas simples a respeito dos dados."

Alguns dos itens que constam na lista de estatísticas fornecida por essa ferramenta são:

Tokens: número de itens (ou ocorrências) ; por exemplo, a frase o João viu o Pedro possui cinco itens : o (1), João (2), viu (3), o (4), Pedro (5). 
- Types: número de formas (ou vocábulos) ; a frase acima possui quatro formas : o (1), João (2), viu (3), Pedro (4).

- Type-Token Ratio: a razão forma/item (ou vocábulo/ocorrência) expressa em porcentagem; a razão forma/item (cuja abreviação é TT em inglês, e VO ou FI em português), na sua forma tradicional, é obtida dividindo-se o total de formas pelo total de itens. Na frase acima, a razão $\mathrm{Fl}$ é $0,8(4 / 5)$. No wordlist, entretanto, transforma-se esse valor em porcentagem; assim, divide-se o total de formas pelo total de itens dividido por cem. Na frase 0 João viu $O$ Pedro, portanto, o valor da razão fornecido pelo programa seria 80 , ou seja, 4 / (5 / 100). Na prática, a razão forma / item indica riqueza lexical do texto. Quanto maior o seu valor, mais palavras diferentes o texto conterá. Em contraposição, um valor baixo indicará um número alto de repetições, o que pode indicar um texto menos rico, ou variado, do ponto de vista de seu vocabulário.

Textos maiores por natureza apresentam mais repetições e, por isso, tendem a possuir valores de $\mathrm{FI}$ mais baixos do que textos curtos. $\mathrm{A}$ razão $\mathrm{FI}$ é, portanto, sensível à extensão do material textual, não sendo confiável para uso em comparações entre textos de tamanhos diferentes (que são a norma, aliás; textos autênticos de extensão igual são extremamente raros)."

Congzhou (2006) aponta que a medida quantitativa de repetições em corpora mais comumente utilizada é a razão $\mathrm{FI}$. 


\subsection{2- Keywords}

"Permite a seleção de itens de uma lista de palavras (ou mais) por meio da comparação de suas frequências com uma lista de referências. $O$ resultado do contraste é uma lista de palavras-chave, ou palavras cujas frequências são estatisticamente diferentes no corpus de estudo e no corpus de referência.

O tamanho recomendado de um corpus de referência é cinco vezes o tamanho do corpus de estudo. Um pesquisador não precisa, necessariamente, coletar ou procurar um corpus de referência maior, pois a quantidade de palavras-chave obtidas seria igualável a quantidades obtidas com corpora maiores.

Para cada palavra-chave encontrada, o programa fornece um valor chamado Keyness (que é o valor do teste estatístico, que o usuário pode escolher entre qui-quadrado ou log-likelihood) e o valor do p" (Sardinha, 2004).

\subsection{3- Concord}

Essa ferramenta produz concordâncias ou listagens das ocorrência de um item específico (chamado palavra de busca ou nódulo, que pode ser formado por uma ou mais palavras) acompanhado do texto ao seu redor (o cotexto). 


\section{8- Vida e obra de Lima Barreto}

\subsection{1- Vida}

Como relatado por Francisco de Assis Barbosa (2003) em sua biografia $A$ vida de Lima Barreto, Afonso Henriques de Lima Barreto nasceu na cidade do Rio de Janeiro em 13 de maio de 1881, filho de dois mulatos, João Henriques de Lima Barreto e Amália Augusta Pereiras de Carvalho. Conheceu desde cedo as adversidades da vida. Perdeu a mãe em 1887, aos seis anos de idade, vítima de tuberculose, golpe do qual jamais se recuperaria totalmente e sentiu-se desde criança discriminado pela cor de sua pele. Em 1890, seu pai, que era tipógrafo da Imprensa Nacional, foi exonerado do cargo em decorrência de divergências políticas na República incipiente, para ser nomeado no mesmo ano escriturário das Colônias de Alienados da Ilha do Governador, lugar para o qual a família se mudou em 1891, quando João Henriques foi promovido a almoxarife. Em 1893 ele se tornou administrador das Colônias.

Em 1899, Lima ingressou na Escola Politécnica, mas não conseguiu passar do segundo ano do curso, tendo sido reprovado cinco vezes em mecânica. Ele atribuiu seu insucesso acadêmico ao preconceito racial vigente na escola.

Em 1902, o pai de Lima Barreto passou a sofrer de uma séria doença mental de natureza psicótica, cujo surto é relatado a seguir:

Logo após o jantar, [João Henriques] foi deitar-se. (...) Tudo parecia normal, sem surpresas. Não passaria pela cabeça de 
ninguém que a desgraça estivesse tão próxima. No meio da noite, porém, o silêncio da pequena casa (...) foi cortado bruscamente por gritos lancinantes que vinham do quarto de João Henriques. $O$ almoxarife delirava. Por entre as frases desconexas que proferia, percebia-se que o pobre homem, alucinado, estava possuído pelo pavor de ser preso. Era a loucura!

— Não deixem a polícia entrar! Não deixem! - gritava e chorava, ao mesmo tempo.

(...) João Henriques continuava imerso e só via pela frente o delegado e os soldados de polícia, armados até os dentes, e todos queriam levá-lo de qualquer jeito para a cadeia. (Barbosa, 2003).

Lima Barreto conviveu durante grande parte de sua vida com a doença de seu pai, que passou a ser uma pessoa reclusa, vítima de surtos psicóticos de tempos e tempos. Na descrição de Barbosa, "João Henriques passava dias inteiros na sua cadeira de balanço, sem falar, nem comer. Sem se mexer sequer, como se fosse um boneco. E só deixava a imobilidade e o mutismo, a que se entregava, para o delírio, quando, transido de pavor, abria a boca no mundo, gritando de inimigos inexistentes."

Em 1903, em decorrência de sua doença mental, João Henriques foi aposentado do cargo de administrador das Colônias de Alienados da llha do Governador e Lima Barreto foi aprovado em segundo lugar no concurso de amanuense na Diretoria do Expediente da Secretaria de Guerra, sendo 
nomeado e empossado. No mesmo ano, os dois foram morar em Todos os Santos, sendo a residência deles conhecida como "a casa do louco."

Em 1905, Lima Barreto começou a escrever Recordações do escrivão Isaías Caminha, obra que seria publicada pela primeira vez em 1909 e, em 1906, iniciou a escrita de Vida e morte de M. J. Gonzaga de Sá. Entre novembro de 1910 e abril de 1911, foram escritas as principais obrasprimas do autor: os contos $A$ Nova Califórnia e O homem que sabia Javanês e o romance Triste fim de Policarpo Quaresma.

Francisco de Assis Barbosa estabelece o ano de 1911 como um marco na vida do escritor: "Não será demais fixar o ano de 1911 como uma nova fase na vida de Lima Barreto, a fronteira que delimita o período mais fecundo de sua atividade de romancista com os primeiros desregramentos boêmios, saturado desde então pelo aborrecimento e pelo desgosto de viver."

A dependência de álcool foi um problema gravíssimo, a partir de então, na vida dele. Nas palavras de Barbosa, ele se transformaria num "pobre homem, viciado no álcool, que lhe consome não somente a saúde, como em grande parte the sacrifica a carreira de escritor."

Imerso num ciclo de decadência física e mental, Lima Barreto passou a perambular pela cidade do Rio de Janeiro de bar em bar, apresentando "um aspecto desnutrido, próprio dos alcoólatras." Em 1914, ele revela no Diário Íntimo: "O maior desalento me invade. Tenho sinistros pensamentos. Ponho-me a beber; paro. Voltam eles e também o tédio da 
minha vida doméstica, do meu viver quotidiano, e bebo. Uma bebedeira puxa outra e lá vem a melancolia. Que círculo vicioso! Despeço-me de um por um dos meus sonhos..."

No mesmo ano, Lima Barreto passou por sua primeira internação psiquiátrica, após ter alucinações visuais e idéias persecutórias, acompanhadas de agitação psicomotora. Permaneceu internado durante dois meses. Voltando a beber, apresentou crise idêntica em 1916, quando foi levado para a Santa Casa de Ouro Fino.

A decadência física de Lima Barreto é muito bem descrita por Ribeiro Couto (1950), em carta a Francisco de Assis Barbosa: "Eu, com 20 anos, tendo lido o Isaías Caminha, o Policarpo Quaresma e o Gonzaga de Sá, não podia compreender como aquele grande escritor, de tão puro estilo, tão natural, precisamente o 'antimulato' em matéria de estilo, fosse o mesmo 'Lima' de barba por fazer, chapéu de palhinha encardida, camisa suja e manchada no peito, roupa coçada mal cheirosa, como uma morrinha que não se sabia se era de vômitos da véspera ou suor azedo."

Até o final de sua vida, Lima Barreto seria internado mais uma vez no Hospital Psiquiátrico, no final de 1919, onde começaria a escrever as anotações para seu livro O Cemitério dos Vivos. O próprio romancista é quem descreve a crise que motivou essa internação: "No começo, eu gritava, gesticulava, insultava, descompunha... Só a minha agitação, uma frase ou outra desconexa, um gesto sem explicação denunciavam que eu não estava na minha razão." (extraído de O Cemitério dos Vivos). 
Lima Barreto morreu em 1ํ de novembro de 1922, 2 dias antes de seu pai, em decorrência de colapso cardíaco.

A seguir, são reproduzidas duas fotos de Lima Barreto do sítio www.sobresites.com, a primeira delas, obtida no auge de sua carreira, e a segunda, retirada de sua ficha de internação no Hospício Dom Pedro II:

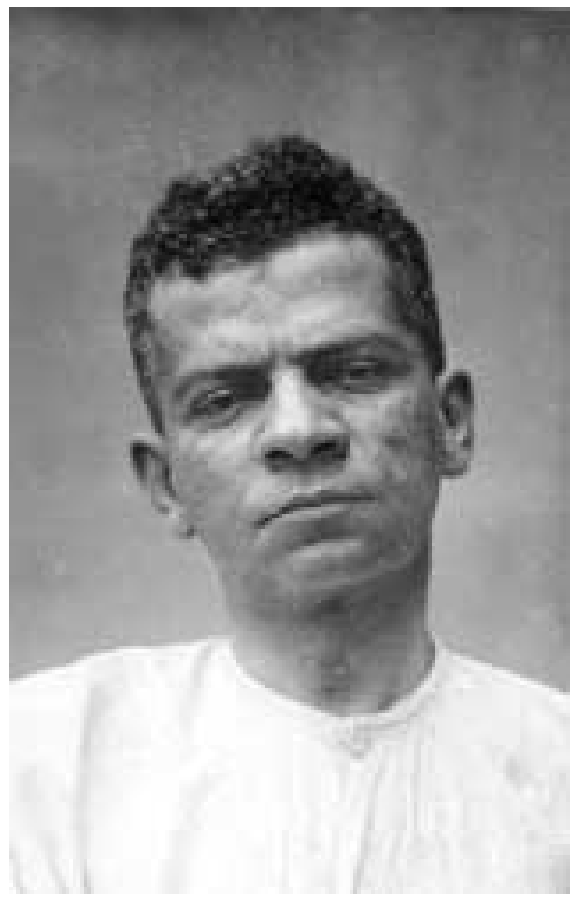

Fig. 1- Lima Barreto internado

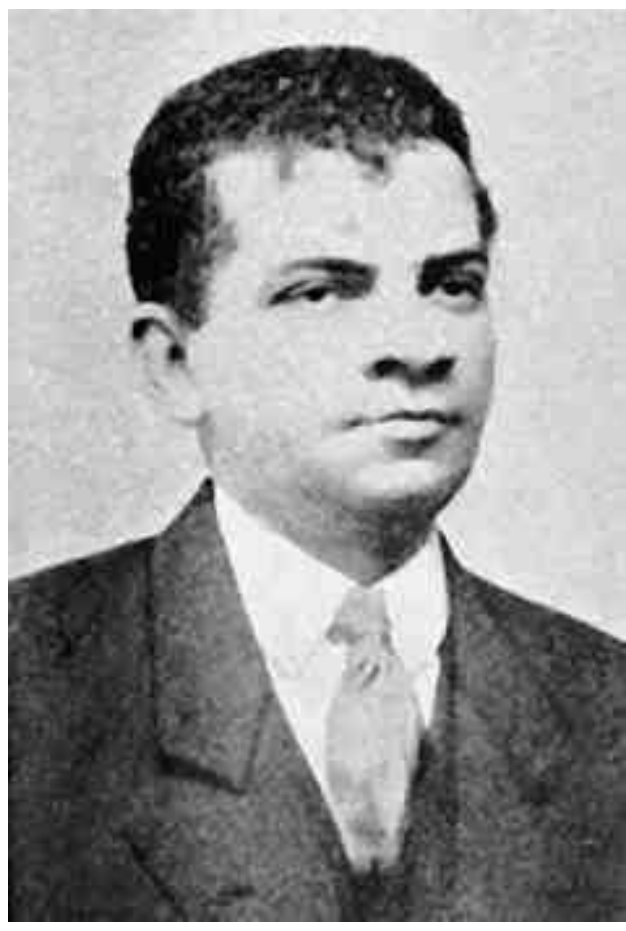

Fig. 2- Lima Barreto no auge da carreira

A seguir, pode-se ver a anamnese extraída do prontuário de Lima Barreto (Livro de Observações n 64, da Seção Pinel do Hospital Pedro II, pp. 144 e segs.), realizada pelo Dr. José Carneiro Airosa, de sua última internação no Hospício Nacional de Alienados, no Rio de Janeiro, em 1919: 
É um indivíduo precocemente envelhecido, de olhar amortecido; fácies de bebedor, regularmente nutrido.

Perfeitamente orientado no tempo, lugar e meio, confessa desde logo fazer uso, em larga escala, de parati; compreende ser um vício muito prejudicial, porém, apesar de enormes esforços, não consegue deixar a bebida.

Por este abuso já passou certa vez três meses no Pavilhão, o que, entretanto, nada adiantou, voltando desde a saída a embriagar-se. Informa que as suas perturbações quando aparecem são em forma de delírios, sempre conseqüentes a um abuso mais forte e mais demorado.

Foi o que sucedeu desta vez, alarmando um seu irmão, que julgou conveniente a sua internação, apesar de seus protestos.

Indivíduo de cultura intelectual, diz-se escritor, tendo já quatro romances editados, e é atual colaborador da Careta.

Fala em seus últimos delírios, reconhecendo perfeitamente o fundo doentio deles, e diz-se certo que tal só sucedeu graças às suas perturbações mentais.

Estes delírios que são facilmente descritos pelo paciente são de caráter terrificante, perseguidor, etc.

Geralmente a amnésia em relação às fases de embriaguez é completa, porém estes últimos delírios, segundo o próprio, 
passaram-se sem que estivesse em completo etilismo, motivo por que é capaz de descrevê-los.

Mãe falecida tuberculosa. Pai vivo, aposentado no serviço da administração das Colônias de assistência a Alienados; há 18 anos não sai de casa, preso de psicastenia ou lipemania, como informa o examinado.

São notáveis os tremores fibrilares da língua e das extremidades digitais apresentados pelo paciente, bem como abalos e tremores dos músculos da face, mormente quando fala. Palavra algo arrastada e meio enrolada, certas vezes. Teve blenorragia e cancro mole, icterícia e febres palustres.

Diagnóstico: Alcoolismo.

\subsection{2- Obra}

A obra de Lima Barreto é composta de romances (Recordações do escrivão Isaías Caminha [1905], Vida e morte de M.J. Gonzaga de Sá [1907], Triste fim de Policarpo Quaresma [1911], Numa e a ninfa [1914], O cemitério dos vivos [1921] e Clara dos Anjos [1922]), artigos para revistas e jornais, contos, sátiras reunidas nos livros Os bruzundangas e Coisas do Reino do Jambom e um Diário íntimo.

Tradicionalmente, Lima Barreto é classificado como um escritor pertencente ao período literário do Pré-Modernismo. Trata-se, porém, de um 
termo genérico, que não constitui uma escola literária, e que é associado à literatura crítica que rompe com a linguagem acadêmica e busca diagnosticar e retratar a realidade brasileira, denunciando a existência de dois "brasis", o rico e o pobre (Blanc, 2007). Ainda segundo esse autor, as características dos escritores desse período são espontâneas, individuais, isoladas e carecem da intenção de constituir um movimento artístico.

As obras de Lima Barreto são caracterizadas pela escrita em tom direto, simples, cujas narrativas muitas vezes se confundem com o estilo jornalístico ou da crônica e com conteúdo de forte crítica à elite e aos políticos. Tais características são opostas às dos movimentos literários anteriores, o parnasianismo e o simbolismo, e antecipam algumas marcas do modernismo, que seria fundado pouco tempo depois da morte de Lima Barreto, com a Semana de Arte Moderna de 1922. Vasconcelos (2001), assim caracteriza o estilo do escritor:

Os romances de Lima Barreto punham em relevo as zonas suburbanas e se engajava, pela ironia e pela sátira, nessa filosofia nacionalista que não poupava a caturrice dos gramáticos e dos puristas, que ainda teimavam em escrever como os portugueses de Portugal... Daí porque os modernistas de 1922 viram na obra de Lima Barreto uma das possibilidades de renovação da narrativa, extraindo dela exemplos de espontaneidade de expressão e uma consciente utilização da linguagem cotidiana, a mais comum e clara possível. O tom zombeteiro, um tanto rancoroso, do autor de Numa e a Ninfa vinha mesmo a calhar nos tempos modernistas, quando 
não se sabia bem em que sentido se devia renovar a narrativa de ficção.

Lima Barreto não obteve em vida o prestígio e o reconhecimento que esperava. Carlos Drummond de Andrade (1981), em artigo no Jornal do Brasil comemorativo do centenário de nascimento do escritor, escreveu: “(...) valho-me de Lima Barreto, cujo centenário de nascimento se comemora hoje com honras que Ihe negaram em vida." Francisco de Assis Barbosa destaca que "Lima Barreto só passou a figurar em histórias de literaturas e compêndios escolares na década de 1930."

\subsection{3- $O$ caráter autobiográfico da obra de Lima Barreto}

Hidalgo (2008), em seu livro Literatura da Urgência - Lima Barreto no domínio da loucura, afirma: "[Lima Barreto] utilizou o eu como origem da escrita, sendo o inventor de uma narrativa que tem em si mesmo a causa principal." Ainda de acordo com essa estudiosa, "Lima criou uma zona de interseção literário-existencial, unindo personagens inventados e questões pessoais." Barbosa (2002), por sua vez, refere que Lima Barreto pertence à categoria dos escritores que mais se confessam através de suas obras e que o próprio romancista teria dito certa vez que tudo o que escrevia eram capítulos de sua memória.

Toda a obra de Lima Barreto é permeada de elementos autobiográficos. Para citar os protagonistas de três de seus mais importantes romances, Tristão de Ataíde (1966) afirma que Isaías Caminha, Policarpo 
Quaresma e Gonzaga de Sá são três "encarnações de sua própria personalidade." Hidalgo reforça essa observação ao afirmar que "Lima escreveu pelo menos quatro romances autobiográficos: Recordações do escrivão Isaías Caminha, Triste fim de Policarpo Quaresma, Vida e morte de M. J. Gonzaga de Sá e O cemitério dos vivos."

Ainda segundo Hidalgo, um dos romances mais autobiográficos de Lima Barreto é Recordações do escrivão Isaías Caminha, "cujo protagonista seria um personagem-representação da faceta do eu pobre e negro do autor". Barbosa (2002), ao comparar Recordações do escrivão Isaías Caminha e Vida e Morte de M. J. Gonzaga de Sá afirma: "Os três personagens, Isaías, Gonzaga e Augusto Machado, o narrador de Vida e morte, se confundem com o seu criador."

Com relação a Triste fim de Policarpo Quaresma, Blanc (2007) afirma: "Dos muitos traços autobiográficos nos personagens de Lima Barreto, a loucura do pai (e futuramente a sua) é refletida, em dado momento, em Policarpo Quaresma. A internação do major é, na verdade, um pretexto para uma reflexão sobre essa condição mental - sempre tão presente na vida de Lima Barreto." Lúcia Pereira (1948) cita Leonardo Flores, um dos personagens de Clara dos Anjos, último romance do autor, que nele colocou alguns traços seus, notadamente o alcoolismo e o histórico familiar de loucura, transformando-o em uma "caricatura do seu criador".

Essa coletânea de relatos autobiográficos na obra de Lima Barreto não poderia excluir aquele que foi provavelmente o livro em que $o$ autor mais 
se expôs, o romance inacabado $O$ cemitério dos vivos. Nele, o leitor é apresentado a Vicente Mascarenhas, personagem que é internado no hospital psiquiátrico por causa de seu problema envolvendo o alcoolismo. Como aponta Hidalgo (2008): "o protagonista de O cemitério dos vivos, Vicente Mascarenhas, traz inúmeras similaridades com o seu autor, num excesso que leva à conclusão: um é o outro. A comparação entre as anotações do diário e o romance flagra inúmeras passagens em que a ficção tange a vida e vice-versa. Assim como Lima, Vicente ingressou no hospício no Natal, reclamando da polícia e contando como o obrigaram a tirar a roupa no ritual de admissão."

\subsection{4- O declínio intelectual de Lima Barreto manifesto em sua última obra, Clara dos Anjos}

Com relação a Clara dos Anjos, último romance escrito em apenas dois meses por Lima Barreto, Barbosa (1981) afirma: "O argumento é pobre, a fabulação um quase nada. [Lima Barreto] pensara em escrever na mocidade um grande romance da escravidão, de que chegou a esboçar alguns capítulos. Não pôde fazê-lo no declínio da vida. O escritor entrara em visível decadência, já não apresentava a força dos primeiros tempos, o ímpeto de que estão impregnadas, por exemplo, as páginas frementes do Recordações do escrivão Isaías Caminha." E complementa: "O livro nasceu fraco. Sem o élan dos primeiros romances." 


\section{4- MÉTODOS}

Para efeito de estudo, a obra de Lima Barreto foi abordada em dois componentes: a forma e o conteúdo. Como forma, entende-se a estrutura básica (Dalgalarrondo, 2008), que será estudada através do uso de técnica linguística. Quanto ao conteúdo, foi feita a análise de trechos de $O$ cemitério dos vivos e do Diário Íntimo de Lima Barreto, suas obras em que a correspondência entre o autor e o narrador é quase completa e em que é descrita a experiência da internação no manicômio. Foram evidenciados os fragmentos em que o autor expressa dados importantes a respeito da realidade encontrada no hospital psiquiátrico, bem como as descrições dos doentes mentais, as visões a respeito da psiquiatria e da loucura e aspectos psicológicos de interesse para a compreensão do que é exposto na obra. Foram analisadas também as formas como a doença mental é representada nos demais romances, através de seus personagens e dos rumos que eles tomam na narrativa.

$\mathrm{Na}$ análise dos personagens e de seus percursos foram utilizados conceitos desenvolvidos pelo linguista russo Mikhail Bakhtin (1895-1975), como carnavalização e cronotopo. Motta (2006), em sua tese de doutorado, mostra a pertinência da aplicação de conceitos bakhtinianos em relação à obra de Lima Barreto.

Em relação à forma, foram obtidos alguns padrões de comparação linguística entre as obras iniciais de Lima Barreto (Recordações do escrivão 
Isaías Caminha e Triste Fim de Policarpo Quaresma) e a última que ele escreveu, Clara dos Anjos. O cemitério dos vivos não entrou nessa análise por tratar-se de obra inacabada, o que poderia enviesar os resultados. Foi usado o software de estudos linguísticos Wordsmith Tools, em sua versão 3.0 .

\section{1- Elementos linguísticos extraídos dos corpora através do uso do software WordSmith Tools}

Para uso do software, as obras de Lima Barreto Recordações do escrivão Isaías Caminha, Triste fim de Policarpo Quaresma e Clara dos Anjos foram baixadas do sítio da internet www.bibvirt.futuro.usp.br (Biblioteca Virtual do Estudante de Língua Portuguesa da USP). Também foram baixadas as seguintes obras de outros escritores da língua portuguesa, escritas em prosa, para constituírem corpora de referência: $A$ profissão de Jacques Pedreira (1911), de João do Rio, O Ateneu (1888), de Raul Pompéia, Dom Casmurro (1899), de Machado de Assis, Inocência (1872), de Visconde de Taunay, A escrava Isaura (1875), de Bernardo Guimarães, Luzia-Homem (1903), de Domingos Olimpio, O cabeleira (1876), de Franklin Távora, O cortiço (1890), de Aluísio Azevedo, O missionário (1891), de Inglês de Souza, O Primo Basílio (1878), de Eça de Queirós, Os sertões (1902), de Euclides da Cunha e Senhora (1875), de José de Alencar. Tais obras foram escolhidas por terem sido escritas em época próxima 
àquela em que Lima Barreto viveu, ilustrando o universo linguístico em que ele esteve imerso.

Cada uma dessas obras foi dividida em sete partes aproximadamente do mesmo tamanho. Cada uma dessas obras, então, deu origem a sete subcorpora, que abrangem o início da obra até o limite de cada uma dessas sete partes. Assim, o primeiro subcorpus engloba o primeiro sétimo da obra, o segundo, os dois primeiros sétimos e assim em diante. O esquema a seguir ilustra esse processo para os três primeiros subcorpora gerados de uma obra em que cada sétima parte possui dois capítulos de igual tamanho:

\section{Subcorpus 3 (3/7 da obra)}

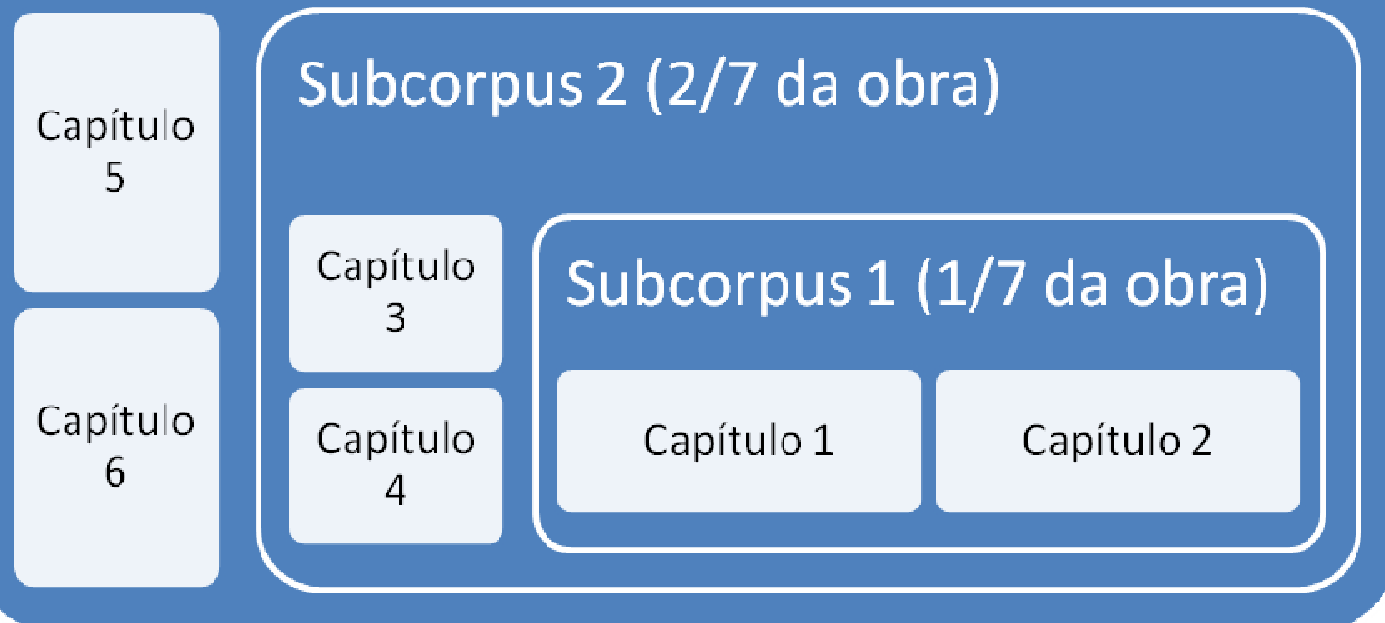

Fig. 3- Esquema mostrando o processo de geração dos subcorpora a partir dos corpora literários.

Foram criados também dois corpora, um que foi chamado de corpus de estudo (CE) e o outro nomeado corpus de referência (CR). 
O CE foi elaborado a partir da junção das três obras de Lima Barreto: Recordações do escrivão Isaías Caminha, Triste fim de Policarpo Quaresma e Clara dos Anjos. O CR, por sua vez, é o resultado da união das demais obras literárias baixadas: $A$ profissão de Jacques Pedreira, $O$ Ateneu, Dom Casmurro, Inocência, A escrava Isaura, Luzia-Homem, O cabeleira, O cortiço, O missionário, O Primo Basílio, Os sertões e Senhora.

\subsection{1- Uso da ferramenta Wordlist}

Sobre os subcorpora criados como ilustrado na figura 3 , foi utilizada a ferramenta wordlist do programa WordSmith Tools. Dessa forma, foram obtidas duas listas de palavras para cada subcorpus (uma em ordem alfabética e outra ordenada por freqüência), além de dados estatísticos, como número de types, tokens e índice type-token. Então, foi construída uma tabela para cada obra literária, constando a evolução desses parâmetros no decorrer da obra. Os dados ilustrados na tabela foram também convertidos em gráfico. Dessa forma, foram comparados os índices type-token das obras de Lima Barreto entre si e dessas com as obras do corpus de referência, procurando-se por diferenças estatísticas.

Considerando-se a possibilidade de um empobrecimento semântico no autor, a hipótese levantada é a de que ocorra uma diminuição do índice type-token comparando-se a obra inicial com a obra final de Lima Barreto.

Para a análise estatística, foi usado o teste qui-quadrado para as curvas do gráfico construído (type x token), tomando-se como referência um 
mesmo valor no eixo das abscissas. O valor de significância foi estabelecido em $5 \%(p<0,05)$.

\subsection{2- Uso da ferramenta Keywords}

As listas de frequência de palavras obtidas para o corpus de estudo e o corpus de referência foram confrontadas, obtendo-se palavras-chave através da utilização do teste estatístico do qui-quadrado (com nível de significância de 5\%). Essas palavras-chave foram então analisadas, em busca daquelas que tinham relação com psicopatologia ou psiquiatria.

\subsection{3- Uso da ferramenta Concord}

Esse recurso foi usado com a finalidade de se encontrar todas as ocorrências das palavras-chave, analisando o contexto em que elas ocorreram. 


\section{5- RESULTADOS}

\section{1- Análise do conteúdo}

5.1.1- Evolução da representação da doença mental na obra de Lima Barreto

a) As obras iniciais (Recordações do escrivão Isaías Caminha e Triste fim de Policarpo Quaresma)

Em Recordações do escrivão Isaías Caminha, observam-se duas passagens que aludem explicitamente a situações que são estudadas pela ciência psiquiátrica. Na primeira delas, o narrador em primeira pessoa faz referência a um louco de rua nos seguintes termos:

(...) lá aparecia, na famosa subdivisão do velho quotidiano, uma clareira de desinteresse, de afastamento do mundo, das cousas vis e baixas. Era (...) um louco que parecia sorrir, na sua loucura, das nossas brutais preocupações de cada dia. Pairava alto, muito longe. (p. 208)

E mais adiante:

Os moços, como eu, tinham um grande prazer em ver como superiormente brilhava, com altas virtudes, a loucura, naquele 
trevoso enquadramento de baixos interesses, de injúrias e sordícia monetária. (p.208)

Pode-se ver, nesse caso, que o autor idealiza a doença mental, como sendo um estado superior que apresenta virtudes em relação à vivência da realidade.

Em outro momento da mesma obra, o personagem Floc (pseudônimo de Frederico Lourenço do Couto), crítico literário de O Globo, comete suicido na redação do jornal. Tal incidente é interpretado pelo narrador Isaías Caminha como uma espécie de redenção diante das mazelas e da desonestidade intelectual que eram características da sociedade da época, e mais especificamente do meio profissional em que ele trabalhava, já que as notícias do jornal eram fabricadas de acordo com os interesses e as vaidades do dono e de seus protegidos. Assim, apesar da antipatia que Isaías nutria por Floc no início do romance, ele passa a ter por ele até certa admiração após seu suicídio, como aponta o seguinte excerto:

(...) fiquei tendo um imenso desprezo, com grande nojo, por tudo quanto tocava às letras, à política e à ciência, acreditando que todas as nossas admirações e respeitos não são mais que sugestões, embustes e ilusões, fabricados por meia dúzia de incompetentes que se apoiam e se impuseram a credulidade pública e à insondável burrice da natureza humana.

Mas, se o meu desprezo e o meu aborrecimento por tudo isso se não fizeram totais, foi porque por vezes senti neles, naqueles 
redatores e repórteres que tinham o cofre das graças, grandes dúvidas, grandes desesperos e fortes vacilações de consciência sobre o próprio valor.

Houve um caso que, por trágico, me ficou eternamente gravado e foi como a demonstração de que ainda havia no fundo de alguns deles uma crença no Sério, no Verdadeiro, na Perfeição. (p.242)

Logo em seguida a essa passagem, Floc se mata com um disparo de revólver na cabeça.

Outra situação relacionada à psiquiatria que ocorre em Recordações de Isaías Caminha é o adoecimento mental de Lobo, gramático do jornal. Diante dos inúmeros erros gramaticais cometidos por seus colegas, ele enlouquece:

Lobo enlouquecera e estava recolhido ao hospício. A sua mania era não falar nem ouvir. Tapava os ouvidos e mantinha-se calado semanas inteiras, pedindo tudo por acenos. Ao médico que Ihe perguntou porque assim procedia, explicou, a muito custo:

- Isto não é língua... Não a posso ouvir... Tudo errado... Que vai ser disto!

- E por que não fala? 
— Os erros são tantos, e estão em tantas bocas, que temo que eles me tenham invadido e eu fale esse calão indecente..." (p. 251)

Aqui, observamos o caráter caricato e cômico da loucura manifesta por esse personagem.

Em Triste fim de Policarpo Quaresma, são dois os personagens que sofrem de distúrbios mentais: o próprio major Quaresma e Ismênia, filha do general Albernaz.

Quaresma, patriota ardoroso, começa a estudar a cultura nacional e o folclore, sem se dar conta de que estava sozinho nessa empreitada. Assim, ao tentar incorporar tradições desconhecidas por todos, começa a ser visto por seus vizinhos e colegas como excêntrico, como ilustrado na seguinte passagem:

Tornava-se (...) preciso arranjar alguma coisa própria original, uma criação da nossa terra e de nossos ares.

Essa ideia levou-o a estudar os costumes tupinambás; e, como uma ideia traz a outra, logo ampliou o seu propósito e eis a razão por que estava organizando um código de relações, de cumprimentos, de cerimônias domésticas e festas, calcados em preceitos tupis.

Desde dez dias que se entregava a essa árdua tarefa, quando (era domingo) Ihe bateram à porta, em meio de seu trabalho. 
Abriu, mas não apertou a mão. Desandou a chorar, a berrar, a arrancar os cabelos, como se tivesse perdido a mulher ou um filho. A irmã correu lá dentro, o Anastácio também, e o compadre e a filha, pois eram eles, ficaram estupefatos no limiar da porta.

— Mas que é isso compadre?

—Que é isso, Policarpo?

- Mas, meu padrinho...

Ele ainda chorou um pouco. Enxugou as lágrimas e, depois, explicou com a maior naturalidade:

— Eis aí! Vocês não têm a mínima noção das coisas da nossa terra. Queriam que eu apertasse a mão... Isto não é nosso! Nosso cumprimento é chorar quando encontramos os amigos, era assim que faziam os tupinambás.

O seu compadre, a filha e dona Adelaide entreolharam-se, sem saber o que dizer. O homem estaria doido? Que extravagância! - Mas senhor Policarpo - disse-lhe o compadre -, é possível que isto seja muito brasileiro, mas é bem triste compadre. (p.277)

Em outro momento, Quaresma também se expõe ao ridículo ao tentar encenar, na festa de seu amigo Albernaz, uma brincadeira chamada Tangolomango, aprendida de um velho poeta: 
Quaresma fez o Tangolomango, isto é, vestiu uma velha sobrecasaca do general, pôs uma imensa máscara de velho, agarrou-se a um bordão curvo em forma de básculo, e entrou na sala. (...)

Por aí, o major avançava, batia com o báculo no assoalho, fazia: hu! hu! hu!; as crianças fugiam, afinal ele agarrava uma e levava para dentro. Assim, ia executando com grande alegria da sala, quando, pela quinta estrofe, Ihe faltou ar, Ihe ficou a vista escura e caiu. Tiraram a máscara, deram-Ihe algumas sacudidas e Quaresma voltou a si. (p.277)

Por fim, há o episódio em que Quaresma é internado em um manicômio e torna-se alvo de chacota por parte de seus colegas de trabalho, após escrever um ofício à Câmara dos Deputados em que solicita que a língua oficial do Brasil passe a ser o tupi-guarani. Os deputados não conseguem se conter diante da proposta absurda que é apresentada a eles:

O burburinho e a desordem que caracterizam o recolhimento indispensável ao elevado trabalho de legislar, não permitiram que os deputados o ouvissem; os jornalistas, porém, que estavam próximo à mesa, ao ouvi-lo, prorromperam em gargalhadas, certamente inconvenientes à majestade do lugar. $\mathrm{O}$ riso é contagioso. $\mathrm{O}$ secretário, no meio da leitura, ria-se discretamente; pelo fim já ria-se o presidente ria-se o oficial da ata, ria-se o contínuo - toda a mesa 
e aquela população que a cerca riram-se da petição, largamente, querendo sempre conter o riso, havendo em alguns tão franca alegria que as lágrimas vieram. (p.291)

Assim, nota-se que a loucura de Policarpo Quaresma é retratada de modo bastante cômico, sendo a caricatura o recurso mais utilizado pelo autor.

O outro personagem do mesmo romance que passa a sofrer de distúrbios mentais no desenrolar da história é Ismênia, após ser deixada pelo noivo, um estudante de odontologia. O sofrimento causado pelo abandono é tão grande que ela definha progressivamente, até morrer. Seu adoecimento mental é assim caracterizado:

(...) enlouquecera de uma loucura mansa e infantil. Passava dias inteiros calada, a um canto, olhando estupidamente mudo, com um olhar morto de estátua, numa atonia de inanimado, como que caíra em imbecilidade; mas vinha uma hora, porém, em que se penteava toda, enfeitava-se e corria à mãe dizendo:

- Apronta-me, mamãe. O meu noivo não deve tardar... é hoje meu casamento. Outras vezes recortava papel, em forma de participações e escrevia: Ismênia de Albernaz e Fulano (variava) participam o seu casamento. 
O general já consultara uma dúzia de médicos, o espiritismo e agora andava às voltas com um feiticeiro milagroso; a filha, porém não sarava, não perdia a mania e cada vez mais se embrenhava o seu espírito naquela obsessão de casamento, alvo que fizeram ser da sua vida a que não atingira, aniquilando-se, porém o seu espírito e a sua mocidade em pleno verdor. (p. 367)

Vê-se, aqui, a loucura sendo decorrente do rompimento de uma relação afetiva e tendo a função de afastar o indivíduo da insuportável realidade de não ter sido desejado pelo outro. No interior da obra, fica claro que Ismênia não nutre um amor genuíno por seu noivo, mas sente-se na obrigação de casar-se por uma imposição social. Lima Barreto faz, portanto, por intermédio desse personagem e de seu adoecimento mental, uma crítica aos valores da sociedade da época.

b) As obras finais (O cemitério dos vivos e Clara dos Anjos)

\section{b.1) A psicopatologia presente em 0 cemitério dos vivos e no Diário} Íntimo

Durante a permanência de Lima Barreto no Hospital Nacional de Alienados, o mesmo descreveu vários pacientes que observou, e futuramente eles passaram a figurar em sua obra. No início do capítulo III 
das anotações para $O$ cemitério dos vivos, o leitor é apresentado aos companheiros de internação, retratados pelo narrador como "delirantes cujos delírios mal compreendo, nessa incoerência verbal de manicômio, em que um diz isto, outro aquilo, e que, parecendo conversarem, as idéias e o sentido das frases de cada um dos interlocutores vão cada qual para o seu lado" (p.1386), ao passo que "outros nada diziam, ou balbuciavam coisas ininteligíveis" (p.1392). Essas são descrições de pessoas com associação frouxa de idéias. Na mesma linha, é descrito um doente no capítulo VI do mesmo livro, que

delira, e o seu delírio é típico, passa das coisas mais opostas e sem intermédio algum logo, presente ou oculto. É muito difícil reproduzir um delírio de um louco, principalmente o deste, que é de uma incoerência inacreditável. Eu quis segui-lo e guardá-lo, já de memória, já por escrito; mas nada pude conseguir, mesmo aproximadamente. Ele acaba em casas de alugar, passa para o curso dos rios, história da Guerra do Paraguai, etc. etc. (p.1399)

Essas alterações psicopatológicas também podem corresponder ao que é chamado atualmente de fuga de ideias.

Outro paciente é descrito mais adiante, com estereotipia verbal e desorganização do pensamento: “(...) um doente que esteve na minha seção foi transferido para outra e lá espiava o A., que vivia pelas salas e corredores a dizer coisas desconexas, palavrões, e repetir, a espaços, a palavra 
pinacoteca, derivada e/ou acompanhada de outras, que não fazem sentido com ela." (p.1421)

O próprio Lima Barreto caracteriza como sendo próprio do delírio, "não ligar nunca as idéias, às vezes só às palavras, outras vezes nem a uma nem a outra coisa, para continuar a sua manifestação em estilhaços de pensamentos, de uma que arrebentou sob a pressão da loucura" (p.1467), o que é uma descrição do fenômeno de desagregação do pensamento.

Um paciente com alucinações é mostrado assim no capítulo IX: “Era um rapaz pálido, de feições delicadas, franzino, que vivia sempre com um lenço na cabeça, bem molhado (...) Uma noite, delirando, ele gritou: - Estão me queimando a cabeça! Atinei logo com o seu delírio, e em breve ele explicou todo o seu sofrimento imaginário (...)" (p.1411)

Ao se referir a um dos colegas de internação que cometeu um homicídio, Lima Barreto descreve uma manifestação de atitude alucinatória da seguinte forma:

(...) simples assassinos me apontaram três [pacientes]; um, na Seção Pinel, e os dois restantes aqui.

O da Seção Pinel é um velho, que anda sempre irrepreensivelmente vestido, muito limpo, engravatado e foi empregado na Central, não sei com que título. Matou um colega, não me disseram por que motivo; mas o certo é que a sua aparência calma, de homem normal, causa um engano à primeira vista. 
Passa assim dias, meses; mas lá vem um minuto, à noite ou de dia, em que ele sai da seção, fazendo gestos de fúria, de raiva e raivosamente a exclamar referindo-se à sua vítima:

— Dá-me um descanso, miserável! (p.1400)

Lima Barreto teve contato desde muito cedo com um indivíduo que sofria de quadro delirante, seu próprio pai. Ele é assim retratado no Diário Íntimo: “(...) não lhe afrouxa a mania que, cada vez mais, é uma só, não varia: vai ser preso; a polícia vai matá-lo; se ele sair à rua, trucidam-no. Coitado, o seu delírio cristalizou-se, tomou forma. Pobre de meu pai! Uma vida cheia de trabalhos, de afanosos trabalhos, acabar assim nesse misterioso sofrimento que compunge!" (p.1248). Aqui o autor fala de cristalização do delírio, que tomou forma, mostrando seu caráter estável e estruturado. Um pouco mais adiante, há nova referência ao delírio do pai: "Pobre insano. Não quer comer e é preciso forçá-lo, e as perseguições que ele tem no espírito não o deixam sossegar." (p.1249) Voltando ao Cemitério dos Vivos, o leitor é apresentado a outro paciente delirante: "É um louco clássico, com delírio de perseguição e grandeza. É um homem inteligente, mas com cultura elementar, e o seu delírio desde que não se o interrogue pela base, parece à primeira vista a mais pura verdade. No começo, ele me enganou; e julguei certo tudo o que dizia, mas, por fim, ele me revelou toda a sua psicose" (p.1391). Aqui, o autor demonstra compreender que o delirante pode ser um indivíduo inteligente e que o delírio necessita ser diagnosticado pela sua base, a partir da qual surgem os conteúdos que o paciente expressa, que podem ser verossímeis, dependendo do caso. Em outro 
trecho, chama à atenção de Lima Barreto, o seguinte aspecto: "Os loucos me pareciam pouco emotivos (...)" (p.1410), o que possivelmente correspondia a uma alteração psicopatológica correspondente aos sintomas negativos encontrados em psicóticos crônicos.

Encontramos também descrições de pacientes com quadros que correspondem à catatonia. Como exemplo, pode-se destacar a seguinte passagem do capítulo V:

Outro [paciente] silencioso interessante é um matuto de Cabo Frio, que parece uma estátua. É de uma grande atonia, de uma inércia que não se concebe. Para deitar-se, é preciso ser trazido para a cama, mas logo se levanta e encosta-se à parede de um corredor e aí fica, até que o tragam de novo. Ama o silêncio e estar de pé. Encostado à parede, hirto, olhos parados, sem brilho nem expressão qualquer, parece uma estátua egípcia, um cimélio de templo. (p.1395)

Ou ainda: "Meu vizinho de dormitório é um rapaz cuja loucura reagiu sobre o seu aparelho vocal a ponto dele mal falar e com esforço. Olha-me estupidamente, e com um olhar parado e de um único brilho, e tem a mania de incapacidade de ingerir qualquer alimento. Tudo se tem experimentado: leite, frutas, até um irrigador; mas é em vão. Ele não ingere nada e, se ingere à força, logo vomita, debilita-se e dá em suar às catadupas.” (p.1408) 
No próximo excerto, do capítulo IV, Lima Barreto declara que o mutismo era uma condição comum no Hospital Nacional de Alienados, como nos diz:

Coisa curiosa, entretanto, os formados nisto ou naquilo, que me apontam aqui, quase todos eles são possuídos de uma mania depressiva que lhes tira não só a enfatuação doutoral, como também se voltam, em geral, a um silêncio perpétuo. Mostraram-me vários, e todos eles eram de um mutismo absoluto. Contudo, um deles, bacharel, o mais mudo de todos, na sua insânia, não se esquecera do anel simbólico e, com um pedaço de arame e uma rodela de não sei o quê, improvisara um, que ele punha à vista de todos, como se fosse de esmeralda. (p.1391)

A puerilidade é também relatada em um paciente com idéias de grandeza, no capítulo VIII de O Cemitério dos Vivos: "O Gato, era um velho, a roçar pelos sessenta anos, cheio de uma loucura infantil de insultar, fazer caretas e julgar-se muito (...)" No final do capítulo, o autor acrescenta um diálogo que teve com Gato:

Ontem, ele me chamou confidencialmente e me disse:

- Você sabe de uma coisa?

- Não.

— Vou para São Paulo e lá me casar com uma filha do S. L., que tem noventa milhões de contos. 
Ele não se contentava com pouco. (p.1409)

Mais um quadro clínico na galeria de personagens de O Cemitério dos Vivos é a oligofrenia, descrita assim:

Era este um menino, moreno, completamente idiota. Tinha as feições regulares, a não ser a boca, os olhos negros cravados nas órbitas, e balbuciava que nem uma criança. Tinha poucas ideias e quatro ou cinco palavras. Parece que tinha mais ideias que palavras. Repetia:

- Papai é mau!

-F. é mau!

—Papai tem dinheiro!

一É mau!

-Que pena! (p.1410)

Um dos pacientes do Hospital que recebem descrição mais extensa é F. P., com quadro de idéias de grandeza, irritabilidade, erotização, labilidade afetiva e insônia, correspondendo muito provavelmente ao que atualmente é conhecido como mania: 
Há um doente aqui, F. P., em que eu vejo misturados o amor e a presunção de inteligência e de saber. É o mais barulhento e rixento da casa. Desde as cinco horas da manhã até às sete ou oito da noite, ri, vive a gritar, a berrar, proferindo as mais sórdidas pornografias. Compra barulho com doentes e guardas, descompõenos, como já disse; mas, dentro em pouco, está ele abraçado com aqueles mesmos com que brigou há horas, há dias.

Há muita coisa de infantil nas suas atitudes, nas suas manias de amor, na estultice de se julgar com grande talento e saber, de provir de uma raça nobre ou parecida. Diz-se descendente de um revolucionário pernambucano, em sexta geração, e que foi fuzilado.

Vi-Ihe a letra e uma carta que escreveu a uma pessoa da família. A letra é positivamente de tolo, graúda e redonda. Tem sempre na boca a palavra formidável: meu talento é formidável; tenho uma força formidável; o poder de Deus é formidável; H. é um general formidável. A sua prosápia de educação, de homem fino e de sala, não impede que, por dá cá aquela palha, empregue os termos mais chulos e porcos. Uma hora diz do médico, do chefe da seção, dos companheiros e amigos os maiores elogios; daqui a pouco, está a descompô-los com os seus termos habituais.

Fila os jornais do médico, mas só para tê-los embaixo do braço, pois não os lê e nota-se mesmo em todos os seus atos, 
gestos e palavras, uma falta de seriação, uma instabilidade mental, mais fácil de perceber, quando se lhe expõe qualquer coisa, do que quando ele pretende narrar um fato ou contar uma anedota. $O$ orgulho dele, além do pai, que é totalmente desconhecido, está nos irmãos, formados nisso e naquilo; entretanto, não o pai, mas estes últimos não escapam da sua língua nas horas de fúria. Tem a acompanhá-lo um guarda particular, que faz pena vê-lo sofrer com ele. A toda a hora e a todo instante, além de outros insultos, está a pôr-Ihe na cara que ele ganha sessenta mil-réis para servi-lo.

velho quer despedir-se, mas, ao que parece, ele precisa muito dessa miséria de ordenado. Não é lá muito velho, mas sofre já de decrepitude. Foi guarda-civil, guarda do hospício e, nesse seu último quartel da vida, para ter com o que viver, tem de aturar o mais insuportável louco que eu tenho conhecido na minha longa convivência com os loucos. Mania de grandeza, delírio de saber, de família, de valentia e de coragem, uma agitação que não o faz dormir, nem deixa o seu guarda dormir, tudo nela concorre para fazê-lo, nesta sombria cidade de lunáticos, uma espécie à parte, e supliciar os que são encarregados de sua vigilância. (p.1389)

Neste trecho, Lima Barreto mostra o quanto é difícil lidar com pacientes com excitação psicomotora e quadros que atualmente são 
caracterizados como maníacos. A seguir, é apresentado mais um paciente com idéias de grandeza:

Há, em muita coisa, um fundo de verdade, mas a exaltação da sua personalidade, a grande conta em que ele tem dos seus talentos, ora de médico, ora de dentista, ora de engenheiro, o seu delírio de grandeza monetária, soa, na verdade que se sente em algumas de suas palavras, como uma nota falsa. A mãe é rica, acaba de receber dois mil contos, os irmãos, cada um tem dois mil contos, etc. etc. Ele mesmo tem tido muito dinheiro e tem dado. Promete-me mundos e fundos. Pijamas de seda, passeios a Petrópolis, dinheiro - a qualidade - tudo bom e fino, vindo do estrangeiro para ele (...). Em toda a sua narração de passeios, etc., não se esquece nunca de dizer o preço do custo das coisas. Apesar de sua prosápia sabichona, é de uma ignorância crassa. Erra na ortografia como uma criança de colégio e a sintaxe é um deus-nosacuda. (p.1393)

Encontram-se também no Cemitério dos Vivos pacientes que o autor caracteriza como epilépticos ("Este último [paciente], que já foi do meu dormitório, é um rapazola de seus dezoito anos, que tem uns ataques de forma epiléptica"), paralíticos, que na época eram comuns em virtude da alta prevalência de neurossífilis ("Era este um estudante, que tivera um ataque e vivia no hospital, para curar os efeitos do insulto, que o deixara 
semiparalítico.") e simuladores ("O outro uxoricida militar parece-me não ter nada [referente a doença mental]. Creio que ele está aqui para fugir a cárcere mais duro. Não se pode compreender este homem assassino; é polido, culto, gosta de leitura e de conversar coisas superiores.").

Enquanto a maior parte dos quadros psicopatológicos é descrita por Lima Barreto em pacientes que conheceu durante a sua internação psiquiátrica, a depressão é apresentada ao leitor no relato em primeira pessoa, sendo o narrador o próprio escritor ou seu alter-ego Vicente Mascarenhas, protagonista de $O$ cemitério dos vivos. O estado afetivo deste fica evidente na seguinte passagem daquele romance, no início do capítulo VII:

Dia de São Sebastião. Um dia feio, nevoento. Olho a baía de Botafogo, cheio de tristeza. Não acho tão bela como sempre achei. Os longes dos Órgãos não se vêem; estão mergulhados em névoa. As montanhas de Niterói estão sem o cobalto de sempre; e as manchas de cortes e chanfraduras nelas aparecem como chagas. $O$ casario está mergulhado, confuso, não se desenha bem no horizonte. Tudo é triste (...)." Fica claro, aqui, como o estado de humor influencia na percepção da realidade, acentuando o caráter cinzento e feio daquele "dia de São Sebastião". (p.1401)

No Diário Íntimo, aparecem outras descrições evidentes de vivências depressivas intensas por parte do escritor, como na seguinte passagem escrita em 16 de outubro de 1908: 
Vai me faltando a energia. Já não consigo ler um livro inteiro, já tenho náuseas de tudo, já escrevo com esforço. Só o álcool em dá prazer e me tenta... Oh! Meu Deus! Onde irei parar?

Tenho um livro (trezentas páginas manuscritas), de que falta escrever dois ou três capítulos. Não tenho ânimo de acabá-lo. Sintoo besta, imbecil, fraco, hesito em publicá-lo, hesito em acabá-lo.

É por isso que me dá gana de matar-me; mas a coragem me falta e me parece que é isso que me tem faltado sempre. (p.1283)

Em 20 de abril de 1914, o tom pessimista e de fracasso persiste, além do conteúdo de morte e a associação do uso de álcool:

Não tenho editor, não tenho jornais, não tenho nada. $\mathrm{O}$ maior desalento me invade. Tenho sinistros pensamentos. Ponhome a beber; paro. Voltam eles e também um tédio da minha vida doméstica, do meu viver quotidiano e bebo. Uma bebedeira puxa a outra e lá vem a melancolia. Que círculo vicioso! Despeço-me de um por um dos meus sonhos. Já prescindo da glória, mas não queria morrer sem uma viagem à Europa, bem sentimental e intelectual, bem vagabunda e saborosa, como a última refeição de condenado à morte. (p.1305) 
Voltando ao Cemitério dos Vivos, o autor mostra como a vivência depressiva interferia negativamente na produção criativa, deixando-o em um estado de apatia e desalento:

Atolava-me na bebida, no desgosto e na apreensão... Pensava bem em morrer, mas me faltavam forças para buscar a morte. Comprava livros e não os lia. Planejava estudos e não os fazia. Delineava obras e não as realizava. Minha capacidade inventiva e criadora, a minha instrução técnica e a minha pretensão eram insuficientes para fabricar um Náutilus, e eu bebia cachaça. (p.1407)

Talvez o relato mais pungente do sofrimento do escritor seja 0 seguinte, em que nem a morte é capaz de trazer o alívio:

Veio-me, repentinamente, um horror à sociedade e à vida; uma vontade de absoluto aniquilamento, mais do que aquele que a morte traz; um desejo de perecimento total da minha memória na terra; um desespero por ter sonhado e terem me acenado tanta grandeza, e ver agora, de uma hora para outra, sem ter perdido de fato a minha situação, cair tão, tão baixo, que quase me pus a chorar que nem uma criança. (p.1448) 
Por fim, a doença que levaria Lima Barreto à decadência física e à morte, o alcoolismo, é relatada por ele em anotação do dia 5 de setembro de 1917 no Diário Íntimo:

De há muito sabia que não podia beber cachaça. Ela me abala, combale, abate todo o organismo, desde os intestinos até à inervação. Já tenho sofrido muito com a teimosia de bebê-la. Preciso deixar inteiramente.

No dia 30 de agosto de 1917, eu ia para a cidade, quando me senti mal. Tinha levado todo o mês a beber, sobretudo parati. Bebedeira sobre bebedeira, declarada ou não. Comendo pouco e dormindo sabe Deus como. Andei porco, imundo.

la para a cidade, quando me senti mal. Voltei para casa, muito a contragosto, pois o estado de meu pai, os seus incômodos, junto aos meus desregramentos, tornam-me a estada em casa impossível. Voltei, porque não tinha outro remédio.

Deitei-me, vomitei e andava com fluxo de sangue, que me levava à latrina freqüentemente. Numa das vezes em que fui, caí e fiquei como morto. Meus irmãos acudiram-me e trouxeram-me a braços(...). Não sei o que se passou; o que sei é que as senhoras da vizinhança acudiram e eu despertei duas horas depois com equimoses nos tornozelos e cercado por elas, cheias de susto. 
Chamaram médico (...); e estou sofrendo a medicação mais penosa que me podia ser imposta. Estou em dieta de fruta e água de arroz, pois o meu organismo tem déficit.

Se não deixar de beber cachaça, não tenho vergonha. Queira Deus que deixe. (p.1318)

Observa-se aqui o sofrimento físico e mental por que passou Lima Barreto em função do alcoolismo, com relato de sintomas gerais e gastrointestinais. As equimoses relatadas, bem como o sangramento digestivo são manifestações comuns em doentes terminais, em função de comprometimento hepático.

\section{b.2) A doença mental em Clara dos Anjos}

O quadro psicopatológico predominantemente descrito em Clara dos Anjos é o alcoolismo. Um dos personagens apresentados ao leitor com esse transtorno é Leonardo Flores. Assim ele é descrito pelo narrador:

Aparecia, também, em certas ocasiões, o Leonardo Flores, poeta, um verdadeiro poeta, que tivera o seu momento de celebridade no Brasil inteiro e cuja influência havia sido grande na geração de poetas que se Ihe seguiram. Naquela época, porém, devido ao álcool e desgostos íntimos, nos quais predominava a loucura irremediável de um irmão, não era mais uma triste ruína de 
homem, amnésico, semi-imbecilizado, a ponto de não poder seguir o fio da mais simples conversa. (p.677)

O narrador expõe, através das características de Flores, as consequências cognitivas do consumo prolongado de álcool, em um quadro semelhante ao que atualmente se chama demência alcoólica. Outro personagem que sofre das sequelas tardias do alcoolismo é Meneses:

Meneses (...) estava amalucado, monomaníaco. Fugia de todas as conversas e teimava em expor o seu sistema de carro motor, sem rodas, absolutamente sem rodas (...). Suprimo as rodas da minha "andotiva" (é assim que o meu aparelho se chama) e imito o meio de locomover-se dos animais terrestres (...). Falava, falava sobre a sua sonhada - andotiva - e bebia parati. (p.736)

Os destinos de Leonardo Flores e de Meneses são trágicos. Após uma noite em que ambos bebem juntos, Meneses morre e Leonardo enlouquece definitivamente, após ver o cadáver do amigo:

Leonardo (...) ao dar com Meneses ao lado, procurou acordá-lo. Foi em vão; o velho estava morto. Um colapso cardíaco o tinha levado (...).

Não dera fé, Leonardo, que alguns transeuntes haviam parado, para ouvir as suas palavras e ver os seus estranhos trejeitos. Os mais curiosos se aproximaram e deram com aquele 
estranho e bizarro espetáculo de um homem, que parecia louco ou bêbedo, a pronunciar coisas incompreensíveis e a gesticular, diante de um pobre velho morto. Chamaram a polícia, e lá foi Leonardo, gesticulando, e falando só, para a delegacia. Meneses tomou o caminho do necrotério, após fotografias e outras precauções policiais.

O primeiro movimento do policial que recebeu Leonardo foi recebê-lo incontinenti para o hospício ou lugar equivalente. $\mathrm{Na}$ verdade, o poeta não dizia coisa com coisa; nem mesmo quem era, informava. (p.740)

Percebe-se que o alcoolismo é retratado, através dos personagens mencionados, como uma condição que leva o indivíduo à degradação física e mental, à morte ou à loucura. Aqui, ela é vista não como um escape, mas como a via final de uma deterioração da pessoa.

\subsection{2- A visão de Lima Barreto sobre a psiquiatria}

O modo como Lima Barreto enxergava a instituição hospitalar psiquiátrica e os fundamentos da Psiquiatria são evidenciados em várias partes de seu Diário Íntimo e do Cemitério dos Vivos.

Duas figuras conhecidas na história da psiquiatria, Juliano Moreira e Henrique Roxo, são mencionadas logo no início de O Cemitério dos Vivos. 
Ao se referir ao primeiro, queixa-se do modo como ele supostamente aplicaria de maneira cega conceitos que vinham da Psiquiatria européia e da pouca empatia que, a seu ver, ele desenvolvia com os pacientes:

Tinha que ser examinado pelo Henrique Roxo. Há quatro anos, nós nos conhecemos. É bem curioso esse Roxo. Ele me parece inteligente, estudioso, honesto; mas não sei por que não simpatizo com ele. Ele me parece desses médicos brasileiros imbuídos de um ar de certeza de sua arte, desdenhando inteiramente toda a outra atividade intelectual que não a sua e pouco capaz de examinar o fato por si. Acho-o muito livresco e pouco interessado em descobrir, em levantar um pouco o véu do mistério - que mistério! - que há na especialidade que professa. Lê os livros da Europa, dos Estados Unidos, talvez; mas não lê a natureza. Não tenho por ele antipatia; mas nada me atrai a ele. (p.1380)

Já Juliano Moreira é retratado de maneira mais positiva, e a ele o autor é grato por tê-lo deixado permanecer na Seção Calmeil, com acesso à biblioteca que o ajudou a passar a tempo durante a sua permanência no hospital: "Na segunda-feira, ates que meu irmão viesse, fui à presença do doutor Juliano Moreira. Tratou-me com grande ternura, paternalmente, não me admoestou, fez-me sentar a seu lado e perguntou-me onde queria ficar. Disse-Ihe que na Seção Calmeil. Deu ordens ao Santana e, em breve, lá estava eu." (p.1382) 
De uma maneira geral, os médicos são vistos com grande desconfiança pelo narrador de O Cemitério dos Vivos, que os considera pessoas pouco reflexivas que, guiadas por modismos científicos, poderiam usar os pacientes como objetos de teste para tratamentos inadequados, como mostra o trecho abaixo:

Eu passei, desde a minha entrada no pavilhão, nas mãos de cinco médicos. Os daquela primeira dependência, já falei; os da Seção Pinel, já aludi. Principalmente ao adjunto ou que outro nome tenha. Não falei do chefe do serviço. Era um moço da minha idade, conhecido da rua, mas conforme meu hábito, já que ele não se deu a conhecer, eu não me dei também. Em rigor, ali, doente indigente, pária social, a mais elementar dignidade fazia eu não o fizesse e, por estar em tal estado, temia-o muito. Sentia, não sei por quê, nesse rapaz, um grande amor à novidade, uma pressa e açodamento, muito pouco científicos, em experimentar o "remédio novo". Percebia-se pelo seu ar abstrato, distraído, que era homem de leituras, de estudos; mas também, por não sei que ar de fisionomia, ou de olhar, que era inquieto e sôfrego. Faltavam-Ihe a capacidade de meditação demorada, da paciência de examinar durante muito tempo o pró e o contra de uma questão; não havia nele a necessidade da reflexão sua, de repensar o pensamento dos outros até admitir como sua a evidência, tida por um outro como tal. Essa sua falta de método, junto a minha condição de desgraçado, davamme o temor de que ele quisesse experimentar em mim um processo 
novo de curar alcoolismo em que se empregasse uma operação melindrosa e perigosa. (...) Pouco lógicos, por isso demasiadamente objetivos; impacientes, por isso aceitando em globo a "autoridade" arriscam-se a de boa fé cometer os erros mais grosseiros e funestos no exercício de sua profissão. Falta-Ihes crítica, não só a mais comum, mas também a necessária do grau de certeza da experiência e dos instrumentos em que as refazem. (p.1483)

Ao ser entrevistado por Henrique Roxo na admissão ao hospital, Lima Barreto responde com ironia: “(...) disse-lhe que tinha sido posto ali por meu irmão, que tinha fé na onipotência da ciência e a crendice do hospício. Creio que Ele não gostou." (p.1380) Ele também desqualifica a psiquiatria em: "Caído aqui, todos os médicos temem pôr logo o doente na rua. A sua ciência é muito curta, muito prevê; mas seguro morreu de velho e é melhor empregar o processo da Idade Média: a reclusão." (p.1399)

A crítica que se observa acima aos psiquiatras é parte de uma crítica maior, que o autor faz reiteradamente ao cientificismo e à doutrina filosófica que o apoiava e estava em voga na época, o Positivismo de Augusto Comte: "Esqueci-me um momento dos meus propósitos de alto debate metafísico, de ferir a Ciência nas suas bases e contestar-Ihe esse caráter de confidência dos Deuses, que os pedantes querem dar-Ihe, para justificarem a vaidade de que tresandam, por saber dela um poucochito, levando, com as suas asserções arrogantes, tristeza no coração dos outros e discórdia entre os 
homens." (p.1436) No mesmo livro de onde é tirada essa citação, 0 Cemitério dos Vivos, encontramos outra em que Lima Barreto admite ter sido adepto do Positivismo em sua juventude, para depois se distanciar do mesmo por considerá-lo dogmático, assim como as religiões: "A minha passagem pelo positivismo foi breve e ligeira. Frequentei o apostolado cerca de um ano; mas, apesar de me ter convencido de muita coisa na escola, eu, até hoje, nunca pude acreditar que aquele conjunto de doutrinas, capazes de falar e seduzir inteligências, fosse capaz de arrebatar corações com o ardor e o fogo de uma fé religiosa." (p.1432)

No entanto, observa-se que a postura de Lima Barreto em relação à ciência e à psiquiatria é ambivalente. Ao mesmo tempo em que as ataca, manifesta crença de que futuramente existiriam tratamentos eficazes para controlar a doença mental e para tornar a internação do doente menos traumática. Ao contar como foi levado ao hospital psiquiátrico dentro de um carro blindado, complementa: "Por mais passageiro que seja o delírio, um ergástulo ambulante [o carro-forte] dessa conformidade só pode servir para exacerbá-lo mais e tornar odiosa aos olhos do paciente uma providência que pode ser benéfica. A medicina, ou a sua subdivisão que qualquer outro nome possua, deve dispor de injeções ou lá que for, para evitar esse antipático e violento recurso, que transforma um doente em assassino nato involuído para fera." (p.1444)

Podem-se fazer com relação a esse fragmento, algumas considerações importantes. Em primeiro lugar, o uso da palavra ergástulo que segundo o dicionário Houaiss, em sua versão eletrônica, significa "na 
Roma antiga, cárcere em que se confinavam os escravos", denota que o autor atribuía ao preconceito racial o modo como foi tratado antes de sua internação. No entanto, ao escrever que esse ato "só pode servir para (...) tornar odiosa aos olhos do paciente uma providência que pode ser benéfica", reconhece que em determinadas situações a internação é necessária, e não necessariamente recurso cruel ou destituído de propósito humanitário. Por fim, ao se referir à "medicina, ou a sua subdivisão que qualquer outro nome possua", reconhece que a psiquiatria é um ramo daquela, em consonância com o pensamento da época. O desejo de que fosse encontrada uma cura para as doenças mentais aparece no próximo fragmento, também de 0 Cemitério dos Vivos: “(...) não queria já que determinassem a origem, ou explicação [da loucura]; mas que tratassem e curassem as mais simples formas." (p.1389)

O autor deixa entrever que, antes de ser internado, pertencia a um círculo da intelectualidade que possuía preconceito contra os psiquiatras, mas após ter contato com um deles no hospital, é obrigado a rever as suas posições: "No dia seguinte à minha entrada na seção e no outro imediato, fui à presença do médico. É um rapaz do meu tempo e deve ter a minha idade; conheci-o estudante; ele, porém, não me conheceu por esse tempo. Nos nossos jornalecos troçamo-lo muito. Eu, porém, não me lembro de qualquer pilhéria a seu respeito feita por mim. Ele me tratou muito bem, auscultou-me, disse-Ihe tudo o que sabia das conseqüências do meu alcoolismo e eu saí do exame muito satisfeito por ter visto no moço uma boa criatura, que não guardava rancor das troças que ele bem podia atribuir a mim.” (p.1384) 
Como argumento contrário às teses de que os internos do hospital psiquiátrico necessariamente sofriam violência e que não havia motivação humanista que justificasse as internações, cita-se o seguinte trecho que descreve o estado de alguns pacientes: "Olham-se os quartos e todos aqueles homens, muitas vezes moços, sem moléstia comum, que não falam, que não se erguem nem da cama para exercer as mais tirânicas e baixas exigências da nossa natureza, que se urinam, que se rebolcariam no próprio excremento, se não fossem os cuidados dos guardas e dos enfermeiros (...)". (p.1463)

Inclusive, Lima Barreto chega a se referir aos funcionários do hospital que eram responsáveis por tomar conta dos internos com alguma ternura e comiseração:

Dias, desde esse tempo, e parece que já mesmo antes, nunca largou esse ofício de pajear malucos. Não é dos mais agradáveis e é preciso, além de paciência e resignação para aturálos, uma abdicação de tudo aquilo que faz o encanto da vida de todo o homem. É ele, por assim dizer, obrigado a viver no manicômio, só podendo ir ter com a família, ou o que com isso se parece, a longos intervalos, demorando-se pouco no lar. Ouvir durante o dia e a noite toda a sorte de disparates, receber as reclamações mais desarrazoadas e infantis, adivinhar as manhas, os seus truques e dissimulações - tudo isto e mais o que se pode facilmente adivinhar, transforma a vida desses guardas, enfermeiros, num verdadeiro sacerdócio. 
Estive mais de uma vez no hospício, passei por diversas seções e eu posso dizer que me admirei que homens rústicos, os portugueses, mal saídos da gleba do Minho, os brasileiros, da mais humilde extração urbana, pudessem ter tanta resignação, tanta delicadeza relativa, para suportar os loucos e as suas manias. Nem todos são insuportáveis; na maioria, são obedientes e dóceis; mas os poucos rebeldes e aqueles que se enfurecem, de quando em quando, são por vezes de fazer um homem perder a cabeça. Tratarei deles mais minuciosamente. Pois o meu Dias, apesar dos gritos, dos gestos de mando, é um homem talhado para pastorear doido, tanto ele como Santana, cuja seção é mais trabalhosa, mas que eu deixei, não porque ele não me tratasse bem, o que ele fez espontaneamente, mas para ter às ordens a biblioteca da Seção Calmeil (...) (p.1383)

Quanto ao tratamento que recebeu durante a internação, Lima Barreto afirma: "Aborrece-me este hospício. Eu sou bem tratado; mas me falta ar, luz, liberdade." (p.1402) Porém, mais uma vez o autor é ambivalente, e em outra parte afirma: "Os guardas, em geral, principalmente os do pavilhão e da seção dos pobres, têm os loucos na conta de sujeitos sem nenhum direito a um tratamento respeitoso, seres inferiores, com os quais eles podem tratar e fazer o que quiserem." (p.1396)

Para ilustrar que a internação de Lima Barreto não foi desmotivada, pode-se citar várias falas em que ele mostra o estado de degradação física ao qual chegou devido ao uso abusivo de álcool: 
Não me preocupava com o meu corpo. Deixava crescer o cabelo, a barba, não me banhava a miúdo. Todo o dinheiro que apanhava bebia. Delirava de desespero e desesperança; eu não obteria nada.

Outras muitas [coisas] me aconteceram, mas são banais a todos os bebedores. Dormi em capinzais, fiquei sem chapéu roubaram-me mais de uma vez quantias vultuosas. Um dia, furtaram-me cerca de quinhentos mil-réis e eu amanheci sentado a uma soleira, na praça da Bandeira, com mil-réis no bolso, que, creio, me deixaram por comiseração os que me roubaram. (p.1387)

A seguir, ele descreve a situação em que se encontrava quando foi internado: “(...) penetrei no pavilhão calmo, tranqüilo, sem nenhum sintoma de loucura, embora toda a noite tivesse andado pelos subúrbios sem dinheiro, a procurar uma delegacia, a fim de queixar-me ao delegado das coisas mais fantásticas dessa vida, vendo as coisas mais fantásticas que se possa imaginar. No começo, eu gritava, gesticulava, insultava, descompunha; dessa forma, vi-as familiarmente, como a coisa mais natural deste mundo. Só a minha agitação, uma frase ou outra desconexa, um gesto sem explicação denunciavam que eu não estava na minha razão.” (p.1388)

Dessa forma, percebe-se, pelo relato do próprio autor, que ele sofria de alterações mentais importantes, que colocava sua vida em permanente risco. Ele mesmo reconheceu isso e passou a ter medo do que lhe poderia acontecer se recebesse alta prematura da internação: "O médico me 
ofereceu alta, mas não aceitei já, porque só quero sair depois do carnaval. Demais, eu penso que o tal delírio me possa voltar, com o uso da bebida." (p.1388)

\subsection{3- O Hospício Pedro II retratado em O cemitério dos vivos}

Lima Barreto, após ter sido internado duas vezes no Hospício Pedro II, deixa a seguinte descrição do mesmo no Capítulo 3 de $O$ cemitério dos vivos:

O hospício é bem construído e seria adequado, se não tivesse quatro vezes o número de doentes para que foi planejado. É obra de iniciativa individual, e a sua construção, pode-se dizer, foi custeada pela caridade pública. Nas dádivas e doações, como sempre, nas obras, muito concorreram os portugueses que enriqueceram no comércio. Os chãos parece que já eram da Santa Casa, mas o edifício propriamente é resultado de dádivas e doações. É grande de fachada, com fundo proporcional, acabamento e remates cuidadosos, um pouco sombrio no andar térreo, mais devido aos acréscimos, do que ao plano primitivo, que se adivinha. Acabado de construir em 1852, todo ele trai, no aspecto exterior, ao gosto pseudoclássico da Revolução e do Império Napoleônico. O seu arquiteto, Domingos Monteiro, foi certamente discípulo da antiga Academia de Belas-Artes e certamente d arquiteto Grandjean de Montigny. É de aspecto frio, severo, solene, com pouco movimento 
nas massas arquiteturais. Custou naquela época cerca de mil e quinhentos contos, e por aí se pode avaliar a tenacidade de José Clemente [Pereira], que o que o ideou e o ergueu, no espaço curto de dez anos (...) Interiormente é dividido em salões e quartos, maiores e menores, com janelas todas para o exterior, e portas para os corredores, que olham para os pátios internos. O meu dormitório ficava no extremo da ala esquerda do edifício (...) e as camas ficavam encostadas ao longo das quatro paredes. Tinha três janelas de sacada para a rua, mas eram inteiramente gradeadas. Via-se o jardim, a rua, os bondes e a montanhas de Niterói e Teresópolis. (p.1465)

No final do Capítulo 1, há outra referência com relação às qualidades arquitetônicas do hospital, que Lima Barreto considerava adequadas para seu propósito:

O hospício é bem construído e, pelo tempo em que o edificaram, com bem acentuados cuidados higiênicos. As salas são claras, os quartos amplos, de acordo com a sua capacidade e destino, tudo bem arejado, com o ar azul dessa linda enseada de Botafogo que nos consola na sua imarcescível beleza (...). (p.1382)

Lima Barreto conta que dividia quarto com mais dezenove internos. Apesar de elogiar a construção do hospício, o autor reclama das condições 
enfrentadas pelos doentes em seu interior, na maioria pessoas dos segmentos inferiores da sociedade:

O mobiliário, o vestuário das camas, as camas, tudo é de uma pobreza sem par. O acúmulo dos doentes, o sombrio da dependência que fica no andar térreo e o pátio interno é quase ocupado pelo pavilhão das latrinas de ambos os andares — tirandoIhe a luz tudo isso Ihe dá má atmosfera de hospital, de emanação de desinfetantes, uma morrinha terrível. Os loucos são de proveniências as mais diversas; originam-se, em geral, das camadas mais pobres da nossa gente pobre. São pobres imigrantes italianos, portugueses, espanhóis e outros mais exóticos; são negros roceiros, que levam a sua humildade, teimando em dormir pelos desvãos das janelas sobre uma esteira ensebada e uma manta sórdida; são copeiros, são cocheiros, cozinheiros, operários, trabalhadores braçais e proletários mais finos: tipógrafos, marceneiros, etc. (p.1381)

Outro dado interessante fornecido por Lima Barreto é a grande proporção de negros na população internada e o fato de vários deles andarem nus: "Alguns não suportam roupa no corpo, às vezes totalmente, outras vezes em parte. Na Seção Pinel, num pátio que ficavam os mais insuportáveis, dez por cento deles andavam nus ou seminus. Esse pátio é a coisa mais horrível que se possa imaginar. Devido à pigmentação negra de 
uma grande parte dos doentes aí recolhidos, a imagem que se fica dele, é que tudo é negro. O negro é a cor mais cortante, mais impressionante; e contemplando uma porção de corpos negros nus, faz ela que as outras se ofusquem no nosso pensamento." (p.1463)

De acordo com o autor, o número de internos na Seção Pinel, a primeira pela qual ele passou, era "de quase duas centenas." (p.1459)

De certa forma, a estrutura do manicômio reflete a da sociedade, ao haver pacientes que o autor denomina como "de primeira classe", que têm tratamento diferenciado e direito a trazerem seus próprios enfermeiros, com os quais Lima Barreto não simpatiza: "Os enfermeiros, na seção em que estou, são em geral bons. Há, porém, uma casta deles que não presta. São os tais particulares. Estes são aqueles que os doentes abastados das primeiras classes são autorizados a trazer." (p.1395)

Com relação à rotina, é destacado que a maior parte do tempo era marcada pelo ócio ou por atividades referentes à manutenção do funcionamento da instituição, como a limpeza de pátios e dos banheiros e a preparação da comida:

Vivi assim cerca de uma semana, condenado ao silêncio e ao isolamento mais estúpidos que se podem imaginar, junto a uma quase imobilidade de preso na solitária. Foram dias atrozes e por isso, só por isso, os que padeci no pavilhão; mas, em breve, depois que um médico (...) ter-me minuciosamente examinado o estado 
mental e nervoso, a monotonia do pátio foi quebrada com o fazer eu as refeições no comedouro dos enfermeiros. (p.1449)

Em outros fragmentos: “(...) e fui com outros levado a lavar o banheiro. Depois de lavado o banheiro, intimou-nos o guarda (...) a tomar banho." (p.1447) e "Os corredores, salões e quartos são encerados e, de manhã, antes e depois do café, de parceria, empregados e doentes dão cera ao assoalho e esfregam-no com escovas presas a grandes tocos de madeira pesada ou aos pés, por atilhos." (p.1477) Não foi encontrado no texto de $O$ cemitério dos vivos nenhuma referência ao tratamento moral como concebido por Philippe Pinel.

Um hábito muito comum entre os internos era o de fumar, que é relatado várias vezes no texto de Lima Barreto, como a seguir: "Os cigarros que [eu] tinha, fumava-os um sobre o outro, guardando as pontas para fabricar novos, com papel comum de jornal. Fumar assim era um meio de afastar o tédio." (p.1448) Ou ainda: "A loucura do cigarro. Um doente, homem rústico, tipo de nosso roceiro, veio para o meu dormitório. Nos primeiros dias, passou bem; mas, não recebendo visitas e, consequentemente, fumo ou cigarro, perdeu a quietude e ficou doido." (p.1424)

A monotonia da rotina no manicômio era superada quando ocorria uma fuga de internos, ou quando havia um motim, que é descrito na seguinte passagem: 
Revolta dos presos na casa-forte, às sete horas da noite. Baderna, etc. A revolta é capitaneada pelo D.E., o tal que subiu no telhado. Estão chegando bombeiros e força de polícia. Previ isto. Os revoltosos são vizinhos de quase metade da Seção Pinel. Armaramse de trancas. Vejo-os cá de cima. O resto da Seção Pinel mantém calma. A nossa está quase sem guardas nem enfermeiros, mas a atitude de todos é de curiosidade. Um acontecimento desses quebra a rotina e distrai. (...) A rua encheu-se; há um movimento de carros, automóveis com personagens, e força de polícia e bombeiros; há toques de corneta - um aspecto de grosso motim. (p.1422)

\subsection{4 - A visão de Lima Barreto sobre o caráter da doença mental}

Lima Barreto, apesar de ter descrito vários estados psicopatológicos durante o tempo em que permaneceu internado no Hospício Dom Pedro II, afirma em $O$ cemitério dos vivos que não percebe maneira de classificar os loucos: "Que dizer da loucura? Mergulhado no meio de quase duas dezenas de loucos, não se tem absolutamente uma impressão geral dela. Há, como em todas as manifestações da natureza, indivíduos, casos individuais, mas não há ou não se percebe entre eles uma relação de parentesco muito forte. Não há espécies, não há raças de loucos; há loucos só.” (p.1388)

Mais adiante, ele pondera que não há uma explicação para a loucura, e que sua origem é incerta: "Há uma nomenclatura, uma terminologia, segundo este, segundo aquele; há descrições pacientes de tais 
casos, revelando pacientes observações, mas uma explicação para a loucura não há." (p.1389) Em seguida, complementa: "Todas as explicações da origem da loucura me parecem absolutamente pueris. Todo o problema de origem é absolutamente insolúvel." No entanto, em vários momentos, Lima Barreto tenta compreender uma explicação para a doença mental, abordando as vertentes psicológica e orgânica e apresentando elementos como o ambiente, a hereditariedade e a teoria da degenerescência, em voga na época.

Com relação à hereditariedade como causa das doenças mentais, o autor se mostra bastante incrédulo, como se observa no seguinte trecho de O cemitério dos vivos: "Apela-se para a hereditariedade que tanto pode ser causa nestes como naqueles; e que, se ela fosse exercer tão despoticamente o seu poder, não haveria um só homem de juízo na Terra (...) A explicação por hereditariedade é cômoda, mas talvez seja pouco lógica." (p.1389) Entretanto, mais adiante, Vicente Mascarenhas apresenta dúvida com relação à influência que seus genes teriam tido para o pouco desenvolvimento mental de seu filho, que não conseguiu se alfabetizar: "Era pela minha descendência que eu sofria particularmente. Que culpa oculta haveria em mim no tenebroso destino que eu augurava para o meu pequeno? A tal hereditariedade dos sábios..." (p.1478)

Os aspectos familiares revelados pelo personagem Vicente Mascarenhas ilustram uma possível influência da teoria da degenerescência. Este apresenta quadro de alcoolismo grave que motiva sua internação psiquiátrica e sua sogra manifesta sinais de loucura em idade avançada. Em 
seu filho, as alterações mentais ocorrem desde a infância. Vicente afirma: "Voltava-me para trás da minha vida e lá via minha sogra louca, às vezes, delirando; às vezes, calada, a olhar tudo com um olhar intraduzível e sobretudo meu filho, seu neto, que passava dos dez anos e não sabia absolutamente nada." (p.1462)

Em outras partes de $O$ cemitério dos vivos, o autor entende que a origem da loucura possa estar em sentimentos vivenciados pela pessoa, em algo que se aproxima da concepção pineliana da gênese dos distúrbios mentais: "Por que os médicos não encontram no amor, desde o mais baixo, mais carnal, até a sua forma mais elevada, desdobrando-se num verdadeiro misticismo, numa divinização do objeto amado; por que — pergunto eu não é fator de loucura também?" (p.1389) Mais adiante, o autor afirma com relação a outro doente: "A sua loucura veio-lhe da vaidade doentia." (p.1421)

Um fator ambiental que é destacado como possível causador dos distúrbios mentais é o contato com os loucos. Nesse caso, há dúvida se a loucura seria um fenômeno transmissível: "Haverá contágio na loucura? Ouvi sempre falar que alienistas notáveis atribuíam a loucura de velhos guardas à ambiência dos hospitais; aqui, contaram-se vários casos. A imitação, contaram-se vários casos. A imitação, que é um poderoso fator de progresso social útil, positivo, pode bem ser contada em sentido contrário, um fator de regresso do indivíduo, e aqui sobra inteligência débil de modo a fazê-la copiar gestos e coisas dos loucos que a cercam." (p.1399) 
O autor complementa essa idéia da gênese da loucura da seguinte forma: "Não sou psicólogo, nem psiquiatra, nem coisa parecida; mas tenho para mim que não é toda estúpida essa hipótese. É preciso levar em linha de conta a capacidade e a resistência mental dos guardas e enfermeiros." (p.1400) Assim, vê-se uma antecipação das teorias contemporâneas do surgimento das psicoses, segundo as quais o bom funcionamento psíquico depende do balanço entre a resistência psíquica e os estressores ambientais a que o indivíduo é submetido.

Talvez o fator etiológico mais importante da doença mental e que foi a origem das crises vivenciadas por Lima Barreto é o vício em álcool. Além das descrições do próprio quadro de alteração mental que motivou suas internações, Lima Barreto apresenta o caso de outro doente que viu no hospital: “(...) um colega de manicômio me chamou para ver um doente da Seção Pinel, que fica na loja, limpando no telhado. Lá fui e vi-o. Era o D.E., parente de um funcionário da casa, de real importância. Tinha o vício da bebida, que o fazia louco e desatinado. Já saíra e entrara no hospício mais de vinte vezes." (p.1404)

Todos os elementos apresentados anteriormente são, por fim, sintetizados na expressão "desarranjo funcional", que se aplica ao pensamento e à inteligência, levando o indivíduo a um estado de degradação praticamente inexorável: “(...) o nosso próprio pensamento, a nossa própria inteligência, que, por um desarranjo funcional qualquer, se há de encarregar de levar-nos àquela depressão de nossa própria pessoa, àquela depreciação da nossa natureza, que as religiões querem semelhante 
a Deus, àquela quase morte em vida." (p.1464) A inexorabilidade da loucura fica mais evidente no seguinte fragmento, em que ela é comparada à morte: "Não há dinheiro que evite a Morte, quando ela tenha de vir; e não há dinheiro nem poder que arrebate um homem da loucura. Aqui, no hospício, com as suas divisões de classes, de vestuário, etc. eu só vejo um cemitério: uns estão de carneiro e outros de cova rasa. Mas, assim e assado, a Loucura zomba de todas as vaidades e mergulha todos no insondável mar de seus caprichos incompreensíveis." (p.1401)

Quanto ao caráter da loucura expresso em O cemitério dos vivos, Lima Barreto não vê na mesma qualquer essência positiva. Pelo contrário, caracteriza-a como fundamentalmente má e alienante, como se pode perceber nos seguintes fragmentos: "O maluco é em geral mau e egoísta, especialmente o Porto, cujo delírio é de grandeza. Raro é o liberal e agradecido." (p.1423) Ou: "O F.P. batuca no piano coisas tão estúpidas como a sua loucura. Não sei como o povo julga que a loucura é sintoma de inteligência e de muito estudo. No hospício, não se vê tal coisa." (p.1414) Tal caráter alienante da doença mental, que retira de seu portador a capacidade de se comunicar coerentemente é ressaltada no seguinte trecho, em que o autor se convence de que, devido à ausência de um interlocutor possível, o melhor é desistir de tentar estabelecer contato com alienados: "Cá estou na Seção Calmeil há oito dias. Raro é o seu hóspede com quem se pode travar uma palestra sem jogar o disparate. Ressinto-me muito disto, pois gosto de conversar e pilheriar; e sei conversar com toda a gente, mas, com esses que deliram, outros a quem a moléstia faz tatibitate, outros que se fizeram mudos 
e não há nada que o faça falar, outros que interpretam as nossas falas de um modo inesperado e hostil, o melhor é calar-se (...)" (p.1385) Em outra parte da obra, o pátio do manicômio é caracterizado como "aquele curral de malucos vulgares".

\subsection{5- Aspectos psicológicos de Lima Barreto presentes no Diário Íntimo e em 0 cemitério dos vivos}

Um dos elementos mais presentes na obra de Lima Barreto é a questão racial. Em várias passagens, são contadas estórias com o objetivo de comprovar que existia discriminação racial, da qual o autor se sentia vítima, como pode ser visto a seguir:

Hoje, comigo, deu-se um caso que, por repetido, mereceume reparo. la eu pelo corredor afora, daqui do Ministério, e um soldado dirigiu-se a mim, inquirindo-me se era contínuo. Ora, sendo a terceira vez, a coisa feriu-me um tanto a vaidade, e foi preciso tornar-me muito sangue-frio para que não desmentisse com azedume. Eles, variada gente simples, insistem em tornar-me como tal (...). Por que essa gente (...) continua a me querer contínuo, por quê? Porque... o que é verdade na raça branca, não é extensivo ao resto; eu, mulato ou negro, como queiram, estou condenado a ser sempre tomado por contínuo. Entretanto, não me agasto, minha vida será sempre cheia desse desgosto (...). (p.1225) 
Apesar de reclamar de preconceito, Lima Barreto se considera superior em relação às pessoas de seu nível social, como apontado no seguinte excerto do Diário Íntimo: "Eu tenho muita simpatia pela gente pobre do Brasil, especialmente pelos de cor, mas não me é possível transformar essa simpatia literária, artística, por assim dizer em vida comum com eles, pelo menos com os que vivo, que, sem reconhecerem a minha superioridade, absolutamente não têm por mim nenhum respeito e nenhum amor que Ihes fizesse obedecer cegamente." (p.1242)

Em outro momento da mesma obra, pode-se ver que o próprio Lima Barreto se refere aos mulatos de forma pejorativa, e acha que sua gente é vulgar e sórdida:

"Ontem, eram onze horas, eu estava no meu quarto, escrevendo, passou um pequeno da vizinhança. Chegando em frente à nossa casa, deu boas-noites. Pelo jeito, pareceu-me que o dera para a minha irmã ou para a tal Paulina, que é uma vulgar mulatinha, muito estúpida, cheia de farofas de beleza e de presunção, que é ou que pode ser namorada. Achei aquilo inconveniente. Que um sujeito, passando por uma casa fechada, desse boas-noites a moças recolhidas num quarto de dormir. Nesse sentido, inquiri minha irmã, que desmentiu. Há em minha gente toda uma tendência baixa, vulgar, sórdida. Minha irmã, esquecida que, como mulata que quer se salvar, deve ter um certo recato, uma certa timidez (...)." (p.1241) 
O autor acredita que será valorizado se for reconhecido em seu trabalho de escritor, preferencialmente entre os brancos, na Europa: "Temo muito em pôr em papel impresso a minha literatura. Essas ideias que me perseguem de pintar e fazer a vida escrava com os processos modernos do romance (...). Ah! Se eu alcanço realizar essa ideia, que glória também! Enorme, extraordinária e — quem sabe? — uma fama europeia." (p.1247)

O sentimento de inferioridade e a timidez interferiram em outro aspecto da vida de Lima Barreto, a sexualidade. Não se sabe de algum relacionamento duradouro que ele tenha tido com mulheres durante a sua vida. No Diário Íntimo, ele afirma: "Tenho vinte e seis anos e, até hoje, ainda não me encontrei com uma mulher de qualquer espécie de maneira tão íntima, de maneira tão perfeitamente a sós; mesmo quando a cerveja, a infame cerveja, me embriaga e me faz procurar fêmeas, é um encontro instantâneo, rápido, de que saio perfeitamente aborrecido e com a bebedeira diminuída pelo abatimento." (p.1276) Nota-se aqui que nessa época a bebida alcoólica já estava sendo utilizada pelo autor como refúgio e a forma depreciativa com que se refere às mulheres.

Diante das intempéries da vida, Lima Barreto adota em alguns momentos a fantasia de lutar de forma heroica contra inimigos imaginários, situações estas em que a desproporção de forças entre o opressor e o oprimido é colossal, como no seguinte fragmento: "Havia-me preparado para todas as eventualidades da vida (...). Imaginei-me amarrado para ser 
fuzilado, esforçando-me para não tremer nem chorar; imaginei-me assaltado por facínoras e ter coragem para enfrentá-los; supus-me reduzido a maior miséria e a mendigar (...)."

Outro aspecto que pôde ser constatado em O cemitério dos vivos foi uma tendência à vitimização do autor, que é visto no excerto: "(...) atribuo a mim mesmo a culpa do que me sucede, ao mesmo tempo culpo F., culpo Z., culpo X. e toda a humanidade, a sociedade em que vivo, mas não quero." (p.1403)

Por fim, percebe-se no seguinte fragmento o papel que a escrita desempenha para Lima Barreto, que é o de conferir sentido existencial para sua vida marcada por sofrimento: "Guardando [essas anotações], eu poderei fazer delas como pontos determinantes da trajetória da minha vida e do meu espírito (...)" (p.1242) 
5.2- Análise da forma: Resultados das análises linguísticas com o uso do Wordsmith Tools

5.2.1- Índices type-token

Usando-se o processo descrito na seção 4.1.1, pôde-se construir a seguinte tabela com os valores de types, tokens e índice type-token para cada uma das obras analisadas : 


\begin{tabular}{|c|c|c|c|}
\hline obra/parte & type & token & índice t/t \\
\hline os sertões 1 & 5787 & 18656 & 31,02 \\
\hline 2 & 10221 & 40413 & 25,29 \\
\hline 3 & 13723 & 62268 & 22,04 \\
\hline 4 & 16090 & 83014 & 19,38 \\
\hline 5 & 17997 & 104695 & 17,19 \\
\hline 6 & 19912 & 128148 & 15,54 \\
\hline 7 & 21743 & 151648 & 14,34 \\
\hline o primo basílio 1 & 3627 & 13506 & 26,85 \\
\hline 2 & 6114 & 30597 & 19,98 \\
\hline 3 & 7647 & 46053 & 16,6 \\
\hline 4 & 9390 & 64513 & 14,56 \\
\hline 5 & 10470 & 81569 & 12,84 \\
\hline 6 & 11896 & 99284 & 11,98 \\
\hline 7 & 12795 & 116734 & 11,12 \\
\hline o missionario 1 & 3445 & 10117 & 33,85 \\
\hline 2 & 6228 & 24934 & 24,98 \\
\hline 3 & 8580 & 40319 & 21,28 \\
\hline 4 & 10746 & 56703 & 18,95 \\
\hline 5 & 12186 & 71719 & 16,99 \\
\hline 6 & 13559 & 87993 & 15,41 \\
\hline 7 & 14797 & 103029 & 14,36 \\
\hline o cortico 1 & 2335 & 7229 & 32,3 \\
\hline 2 & 4536 & 19294 & 23,51 \\
\hline 3 & 5991 & 30005 & 19,97 \\
\hline 4 & 7618 & 41550 & 18,33 \\
\hline 5 & 8756 & 52625 & 16,64 \\
\hline 6 & 9915 & 65175 & 15,21 \\
\hline 7 & 10800 & 76647 & 14,09 \\
\hline o cabeleira 1 & 1527 & 3855 & 39,61 \\
\hline 2 & 3483 & 12622 & 27,59 \\
\hline 3 & 4733 & 19672 & 24,06 \\
\hline 4 & 5092 & 22713 & 22,42 \\
\hline 5 & 6377 & 30825 & 20,69 \\
\hline 7183 & 37770 & 19,02 \\
\hline 8060 & 45106 & 17,87 \\
\hline & & & \\
\hline 2 & & & \\
\hline & 3 & &
\end{tabular}

\begin{tabular}{|c|c|c|c|}
\hline obra/parte & type & token & índice t/t \\
\hline escrava isaura 1 & 1035 & 2712 & 38,16 \\
\hline 2 & 2724 & 10203 & 26,7 \\
\hline 3 & 4133 & 18158 & 22,76 \\
\hline 4 & 5419 & 26223 & 20,67 \\
\hline 5 & 6419 & 34101 & 18,82 \\
\hline 6 & 7178 & 42209 & 17,01 \\
\hline 7 & 7780 & 48345 & 16,09 \\
\hline dom casmurro 1 & 1441 & 4296 & 33,54 \\
\hline 2 & 3142 & 13519 & 23,24 \\
\hline 3 & 4388 & 22592 & 19,42 \\
\hline 4 & 5581 & 32557 & 17,14 \\
\hline 5 & 6451 & 41802 & 15,43 \\
\hline 6 & 7282 & 50774 & 14,34 \\
\hline 7 & 8190 & 61711 & 13,27 \\
\hline ateneu 1 & 2914 & 7157 & 40,76 \\
\hline 2 & 5621 & 17121 & 32,83 \\
\hline 3 & 8246 & 28340 & 29,1 \\
\hline 4 & 9981 & 36026 & 27,7 \\
\hline 5 & 11446 & 43734 & 26,17 \\
\hline 6 & 12624 & 51080 & 24,77 \\
\hline 7 & 13607 & 57500 & 23,66 \\
\hline a profissão 1 & 1080 & 2547 & 42,4 \\
\hline 2 & 2655 & 9198 & 28,86 \\
\hline 3 & 3993 & 15939 & 25,05 \\
\hline 4 & 5030 & 22415 & 22,44 \\
\hline 5 & 6049 & 29238 & 20,69 \\
\hline 6 & 6998 & 37720 & 18,55 \\
\hline 7 & 7732 & 44917 & 17,21 \\
\hline & & & \\
\hline & & & \\
\hline & & &
\end{tabular}

Tabela 1- Valores de types, tokens e índice type-token para cada uma das partes das obras literárias de referência. 
Para as obras de Lima Barreto, os valores foram os seguintes:

\begin{tabular}{|c|c|c|c|}
\hline obra/parte & type & token & índice $\mathrm{t} / \mathrm{t}$ \\
\hline clara dos anjos 1 & 957 & 2319 & 41,27 \\
\hline 2 & 2884 & 9316 & 30,96 \\
\hline 3 & 4148 & 15944 & 26,02 \\
\hline 4 & 5344 & 23105 & 23,13 \\
\hline 5 & 6075 & 29751 & 20,42 \\
\hline 6 & 6976 & 37145 & 18,78 \\
\hline 7 & 7890 & 45131 & 17,48 \\
\hline isaías caminha 1 & 1473 & 3749 & 39,29 \\
\hline 2 & 3627 & 12158 & 29,83 \\
\hline 3 & 5396 & 22032 & 24,49 \\
\hline 4 & 6824 & 30846 & 22,12 \\
\hline 5 & 8000 & 38854 & 20,59 \\
\hline 6 & 9121 & 48069 & 18,97 \\
\hline 7 & 10231 & 57078 & 17,92 \\
\hline triste fim 1 & 1670 & 4846 & 34,46 \\
\hline 2 & 3824 & 14878 & 25,7 \\
\hline 3 & 5469 & 24063 & 22,73 \\
\hline 4 & 6802 & 33395 & 20,37 \\
\hline 5 & 8105 & 42944 & 18,87 \\
\hline 6 & 9219 & 52443 & 17,58 \\
\hline 7 & 10235 & 61924 & 16,53 \\
\hline
\end{tabular}

Tabela 2- Valores de types, tokens e índice type-token para as obras de Lima Barreto. 
Os valores de types e tokens foram colocados em um gráfico de linha para cada uma dessas obras, sendo que as obras de Lima Barreto estão destacadas :

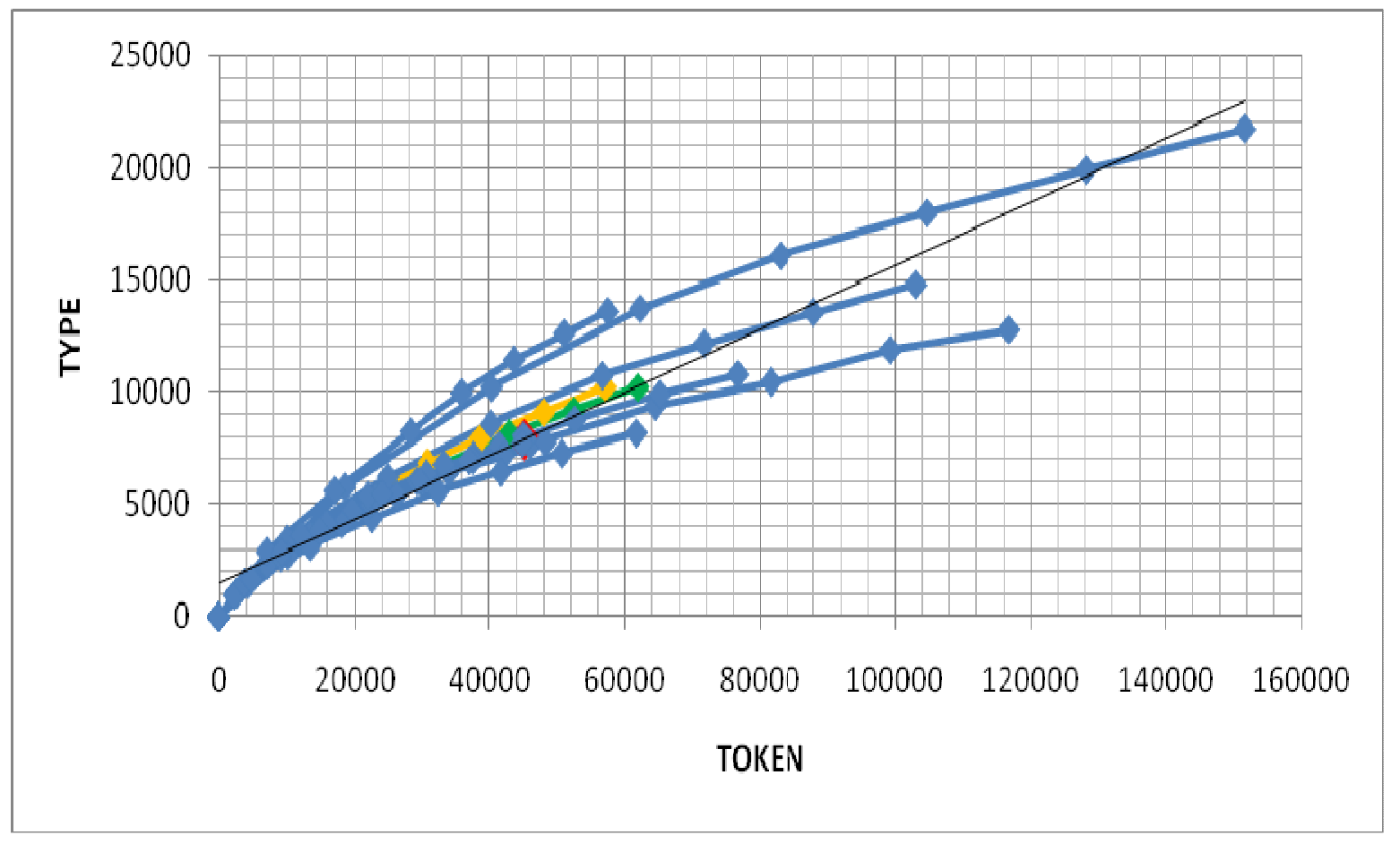

Gráfico 1- Valores evolutivos de type e token para as obras analisadas. (VerdeTriste Fim de Policarpo Quaresma; Amarelo- Recordações do Escrivão Isaías Caminha; Vermelho- Clara dos Anjos). 
A seguir, são representadas apenas as curvas referentes às obras de Lima Barreto:

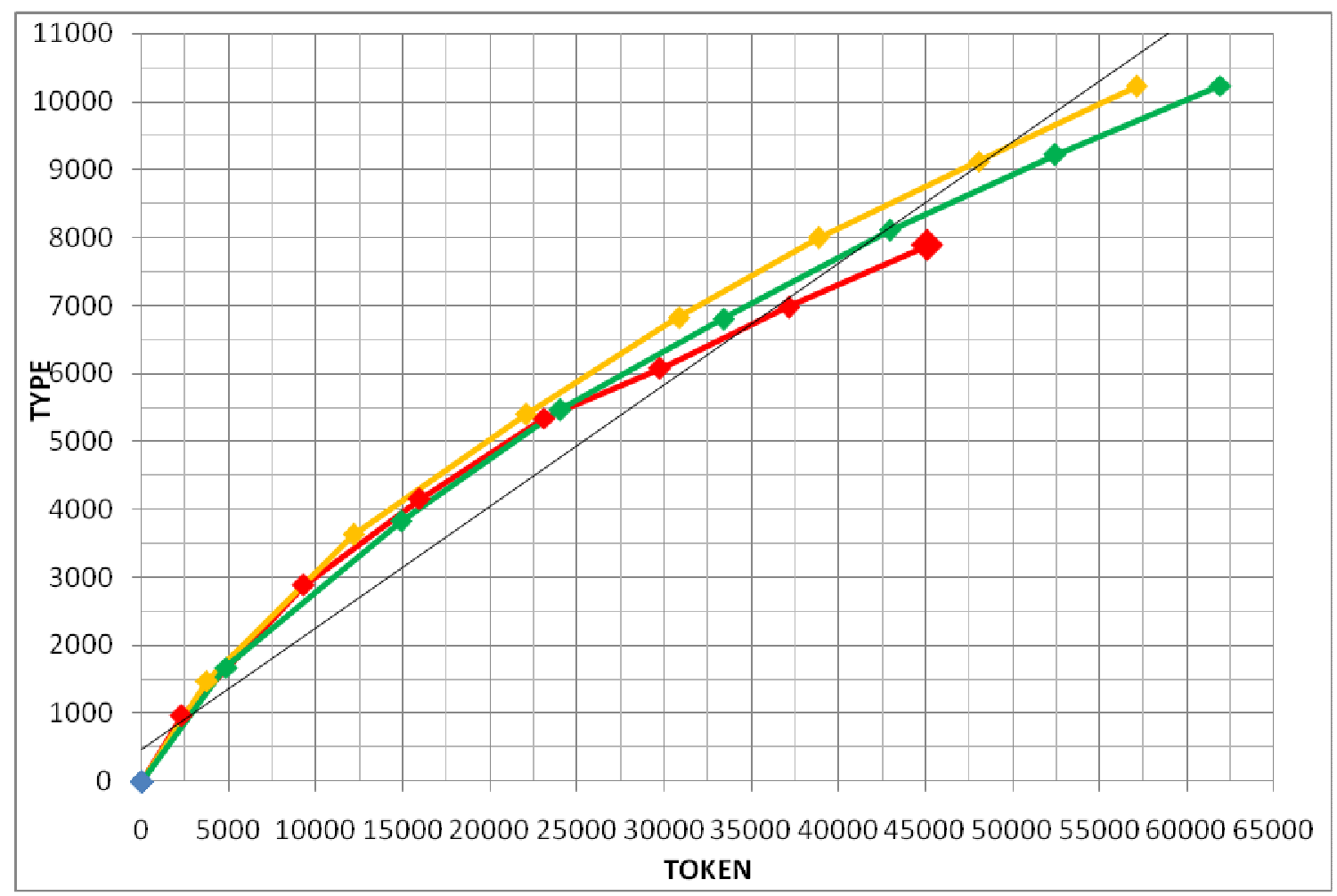

Gráfico 2- Valores evolutivos de type e token para as obras de Lima Barreto. (Verde- Triste Fim de Policarpo Quaresma ; Amarelo- Recordações do Escrivão Isaías Caminha ; Vermelho- Clara dos Anjos).

Percebe-se no gráfico que a partir de 25.000 tokens, Clara dos Anjos passa a ser a obra com o menor número de types, ocupando o lugar de Triste fim de Policarpo Quaresma. Por volta de 20.000 tokens, não houve diferença estatisticamente significativa entre Clara dos Anjos e Triste fim $(p=0,33)$, mas houve significância estatística $(p<0,05)$ entre os outros dois pares (Recordações do escrivão Isaías Caminha e Clara dos Anjos e 
Recordações e Triste fim). Em 30.000 e 40.000 tokens, há diferença estatística entre todas as obras $(p<0,05)$.

\subsection{2- Uso da ferramenta Keywords}

Comparando-se o corpus de estudo (CE) com o corpus de referência (CR), são relacionadas as 10 primeiras palavras-chave em ordem decrescente do índice do valor do qui-quadrado. Também é incluída a 130aa palavra (mania), de interesse para o presente estudo:

\begin{tabular}{|c|c|c|c|c|c|c|c|}
\hline & palavra & $\begin{array}{c}\text { frequência } \\
\text { (CE) }\end{array}$ & $\begin{array}{c}\% \\
(\mathrm{CE})\end{array}$ & $\begin{array}{c}\text { frequência } \\
\text { (CR) }\end{array}$ & $\begin{array}{c}\% \\
\text { (CR) }\end{array}$ & $\begin{array}{c}\text { Qui- } \\
\text { quadrado }\end{array}$ & $\mathrm{p}$ \\
\hline 1 & quaresma & 273 & 0,17 & 6 & & 955,4 & $<0,000001$ \\
\hline 2 & cassi & 239 & 0,15 & 0 & & 885,3 & $<0,000001$ \\
\hline 3 & ricardo & 163 & 0,1 & 8 & & 541,8 & $<0,000001$ \\
\hline 4 & doutor & 259 & 0,16 & 146 & 0,02 & 479,7 & $<0,000001$ \\
\hline 5 & meneses & 142 & 0,09 & 21 & & 407,9 & $<0,000001$ \\
\hline 6 & ele & 928 & 0,57 & 2155 & 0,24 & 402,1 & $<0,000001$ \\
\hline 7 & jornal & 160 & 0,1 & 46 & & 389,5 & $<0,000001$ \\
\hline 8 & major & 157 & 0,1 & 52 & & 364,7 & $<0,000001$ \\
\hline 9 & floc & 76 & 0,05 & 0 & & 281,5 & $<0,000001$ \\
\hline 10 & albernaz & 76 & 0,05 & 0 & & 281,5 & $<0,000001$ \\
\hline 130 & mania & 27 & 0,02 & 18 & & 41,7 & $<0,000001$ \\
\hline
\end{tabular}

Tabela 3 - Palavras-chave, confrontando-se o corpus de estudo com o corpus de referência. 


\subsection{3- Uso da ferramenta Concord}

As ocorrências da palavra mania foram procuradas, utilizando-se a ferramenta Concord. Para cada ocorrência, foi analisado o contexto em que ocorreu, sendo atribuída a etiqueta $p$ nos casos em que mania possuía o significado de doença mental e $\mathrm{n}$ para as demais situações. São relacionadas a seguir a ocorrências no corpus de estudo e no corpus de referência.

\begin{tabular}{|c|c|c|c|c|c|c|c|}
\hline$n^{\circ}$ & \multicolumn{3}{|c|}{ Contexto } & Sig & livro & palavra $n^{\circ}$ & $\%$ \\
\hline 1 & a moça começou a definhar, e, se a & mania & parecia um pouco atenuada, o seu o & $p$ & triste fim & 56.431 & 72 \\
\hline 2 & loucura declarada, a exaltação do eu, a & mania & de não sair, de se dizer perseguid & $p$ & triste fim & 18.068 & 23 \\
\hline 3 & não corria alegre. Meneses tinha a sua & mania & Flores, a dele; e ambos, durante e & $n$ & clara dos anjos & 45.664 & 77 \\
\hline 4 & ocêncio Bustamante também tinha a mesma & mania & demandista. Era renitente, teimoso $\mathrm{n}$ & $n$ & triste fim & 11.457 & 15 \\
\hline 5 & uase formavam cauda na redação. Era uma & mania & A uns dizia: "Procure me em casa" & $n$ & recordações & 56.168 & 72 \\
\hline 6 & o começo uma extravagância, uma pequena & mania & se apresentou logo em insânia dec & $n$ & triste fim & 13.292 & 17 \\
\hline 7 & nário de caricaturas... Havia nisso uma & mania & pueril ou o que ra? Não se manife & $n$ & recordações & 6.640 & 9 \\
\hline 8 & outro Florêncio. Aqueles livros, aquela & mania & de leitura... Pra que el & $n$ & triste fim & 13.043 & 17 \\
\hline 9 & tros, tão simples e tão inocente na sua & mania & de violão, ele não poria mais os o & $n$ & triste fim & 64.468 & 83 \\
\hline 10 & entreespírito que ele queria ter. A sua & mania & era ser um ironista, à moda ingles & $n$ & recordações & 39.647 & 51 \\
\hline 11 & Entretanto ele cultivava. Era a sua & mania & o seu vício, uma teimosia de cadu & $n$ & triste fim & 58.271 & 75 \\
\hline 12 & fazia mal experimentar. É uma & mania & de seu amigo, Senhor Ricardo, esta & $n$ & triste fim & 3.403 & 5 \\
\hline 13 & iculdade de locomover se, não deixava a & mania & inócua da política e ia votar, com & $n$ & clara dos anjos & 3.308 & 6 \\
\hline 14 & filha, porém, não sarava, não perdia a & mania & e cada vez mais se embrenhava e se & $p$ & triste fim & 47.159 & 61 \\
\hline 15 & tude e a ternura no falar, mas quando a & mania & Ihe tomava ficava um tanto seco e & $p$ & triste fim & 18.875 & 24 \\
\hline 16 & rdem, delicada, entretanto, suportava a & mania & de Ricardo, mesmo porque já começa & $n$ & triste fim & 20.115 & 26 \\
\hline 17 & vam se voltados para o calhamaço, têm a & mania & livresca, e não conhecem a verdade & $n$ & recordações & 45.016 & 58 \\
\hline 18 & isso Quaresma, meu Concubi! Volta à & mania & antiga de redigir em Tupi. & $p$ & triste fim & 33.103 & 42 \\
\hline 19 & ocasião em que ele exprobou essa nossa & mania & de empregos e doutorado, citando o & $n$ & recordações & 14.722 & 19 \\
\hline 20 & contecimentos que assistia. A sua única & mania & era beber e dizer se valente. Topa & $n$ & clara dos anjos & 8.083 & 14 \\
\hline 21 & ra e estava recolhido ao hospício. A sua & mania & era não falar nem ouvir. Tapava os & $p$ & recordações & 61.726 & 79 \\
\hline 22 & escrever, meteu se na palestra. Tinha a & mania & do "espírito"; mas não era própria & $n$ & recordações & 39.633 & 51 \\
\hline 23 & riste e absorvido no seu sonho, e na sua & mania & Seu pai a trazia às vezes, aos do & $p$ & triste fim & 17.547 & 23 \\
\hline 24 & bém. Aquele tal preto continuava na sua & mania & de querer fazer a modinha dizer al & $n$ & triste fim & 26.757 & 34 \\
\hline 25 & tor" Meneses, um velho hidrópico, com a & mania & de saber todas as ciências, vivend & $p$ & clara dos anjos & 14.403 & 25 \\
\hline 26 & "esquentados", cada um dava para a sua & mania & Meneses explicava a mecânica suti & $\mathrm{p}$ & clara dos anjos & 45.499 & 77 \\
\hline 27 & ia pior, cada vez mais abismada na sua & mania & enfraquecendo se de corpo. O gene & $p$ & triste fim & 52.452 & 67 \\
\hline
\end{tabular}

Tabela 4 - Ocorrências da palavra mania no corpus de estudo. ( $\mathrm{P}=$ significado de doença mental ; $\mathrm{N}=$ outros significados ; palavra $\mathrm{n}^{\circ}=$ posição que a palavra ocupa na ordem do livro ; \%= porcentagem da obra que é anterior à palavra). 


\begin{tabular}{|c|c|c|c|c|c|c|c|}
\hline$n^{\circ}$ & \multicolumn{3}{|c|}{ Contexto } & Sign. & livro & palavra $n^{\circ}$ & $\%$ \\
\hline & ra isto. Sempre a mesma coisa! Sempre a & mania & de fazer bem, em prejuízo próprio. & $\mathrm{n}$ & o missionário & 71.334 & 60 \\
\hline 2 & tíveis antigos. Acácio tornara-se a sua & mania & admirava a sua figura e a sua gra & $\mathrm{n}$ & o primo basilio & 7.961 & 6 \\
\hline 3 & ho da civilização"! O português tem a & mania & da retórica...- disse Jorge & $\mathrm{n}$ & o primo basîio & 93.345 & 65 \\
\hline 4 & o aos pés de Nossa Senhora, escapavamà & mania & geral do selo, melhor, à geral nec & n & o ateneu & 34.687 & 48 \\
\hline 5 & de folha; achava despropositada aquela & mania & de se porem a chafurdar todos os $d$ & n & o primo basilio & 20.551 & 14 \\
\hline 6 & eve na moda, e para alguns degenerou em & mania & Como um dos leões portugueses es & $\mathrm{p}$ & senhora & 44.650 & 47 \\
\hline 7 & omo uma visita e ele não podia perder a & mania & de que era muito superior ao amigo & $\mathrm{p}$ & a profissão & 11.911 & 19 \\
\hline 8 & abores! Fonseca arrependia-se daquela & mania & que tinha de servir a toda a gente & n & o missionário & 71.138 & 60 \\
\hline 9 & adas fazer pelo governo e tinha a dupla & mania & dos automóveis e das mulheres. Bel & n & a profissão & 6.832 & 11 \\
\hline 10 & do ela morresse... Jorge zangou-se. Que & mania & de falar em coisas ridículas! $\mathrm{Ma}$ & $n$ & o primo basîlio & 92.987 & 64 \\
\hline 11 & o catita. O pé era o seu orgulho, a sua & mania & a sua despesa. Tinha-o bonito e $p$ & n & o primo basilio & 20.696 & 14 \\
\hline 12 & rá isso, observou o mineiro, curá lo da & mania & de não ouvir os outros que que conhece & $n$ & inocência & 26.836 & 35 \\
\hline 13 & os mordomos, os flirts dos prínciper, a & mania & que o imperador tinha de trair a $\mathrm{i}$ & $n$ & a profissão & 16.675 & 27 \\
\hline 14 & á-lo. - Não tinha que fazer... Deu-me a & mania & da limpeza... Estava aborrecida, & $n$ & o primo basilio & 92.878 & 64 \\
\hline 15 & to enfastiada: - Quer mais água! Olha a & mania & pôs-se agora a chafurdar à meia-n & $n$ & o primo basîlio & 31.854 & 22 \\
\hline 16 & causa primeira, pois se não fora a sua & mania & de passar o S. João nas praias, o & $\mathrm{n}$ & o missionário & 70.060 & 59 \\
\hline 17 & que o velho estava sonhando com chuva, & mania & de sertanejos, que não pensam nout & n & luzia-homem & 58.643 & 73 \\
\hline
\end{tabular}

Tabela 5 - Ocorrências da palavra mania no corpus de referência.

Os achados das ocorrências da palavra mania no corpus de estudo e no corpus de referência podem ser resumidos na seguinte tabela:

\begin{tabular}{|l|c|c|c|}
\hline & ocorrências de "mania" & Significado como loucura & Porcentagem \\
\hline CE & 27 & 10 & $37,04 \%$ \\
\hline CR & 17 & 2 & $11,76 \%$ \\
\hline
\end{tabular}

Tabela 6- Síntese dos achados da ocorrência da palavra mania no corpus de estudo (CE) e no corpus de referência (CR).

Foi observada uma tendência $(p<0,10)$ na direção do uso maior da palavra mania com significado de doença mental no corpus de estudo com relação ao corpus de referência. 


\section{6- DISCUSSÃO}

\section{1- Lima Barreto, psiquiatria e doença mental}

Serão divididas, para efeito de discussão, as análises das representações da doença mental e da psiquiatria por Lima Barreto em dois grupos: relatos documentais ( $O$ cemitério dos vivos) e relatos ficcionais (Recordações do escrivão Isaías Caminha, Triste fim de Policarpo Quaresma e Clara dos Anjos). Até certo ponto, essa divisão é arbitrária, porque o limite entre a fiç̧ão e o relato documental é impreciso. No entanto, em virtude das características de $O$ cemitério dos vivos, que é predominantemente descritivo e calcado diretamente na experiência inaudita do autor com a doença mental, optou-se por essa forma de agrupamento de sua obra.

\subsection{1- Relatos documentais da doença mental: 0 cemitério dos vivos}

Procurou-se mostrar neste trabalho vários trechos da obra $O$ cemitério dos vivos de Lima Barreto em que é retratada a visão do autor sobre a doença mental e a ciência psiquiátrica de sua época. Esse romance fornece elementos bastante próximos da realidade do distúrbio mental e do tratamento psiquiátrico por ter sido escrito com base na experiência do autor durante a sua internação no Hospício Nacional dos Alienados. Para o pesquisador em história da psiquiatria, tal visão é extremamente 
enriquecedora, por permitir o acesso a concepções sobre esses temas por parte de um sujeito perspicaz, bem articulado, ótimo observador e que não fazia parte da classe psiquiátrica da época. Assim, não se estaria diante dos vieses de uma exposição feita por um alienista, o que confere grande credibilidade ao relato do autor.

Inicialmente, podem-se fazer algumas considerações com relação à rotina do hospital psiquiátrico retratado em $O$ cemitério dos vivos. Apesar dos relatos de maus tratos e até mesmo de tortura empregados contra os doentes mentais do Hospício Nacional de Alienados na República Velha (Engel, 2001), Lima Barreto não faz qualquer menção aos mesmos. Pelo contrário, às vezes até refere ter sido bem tratado pelos funcionários do hospital e se compadece deles. Outro aspecto interessante diz respeito à rotina dos internos, marcada por atividades relacionadas ao funcionamento e à manutenção da instituição. Não são mencionados outros elementos terapêuticos relacionados ao tratamento moral, que estava em voga na época por influência da psiquiatria francesa, de Pinel e Esquirol (Dalgalarrondo e Oda, 2007). Lima Barreto faz menção, também, à superlotação do hospital psiquiátrico e à predominância de elementos das classes sociais mais baixas, fato que está documentado em estudo de Rey, de 1875, citado por Postel e Quétel (1983).

Quanto às condições em que os doentes mentais se apresentavam na instituição, Lima Barreto descreve em inúmeras passagens a degradação pela qual passavam. No entanto, atribui a mesma predominantemente à alienação mental, e não à internação. No momento atual, em que várias 
práticas psiquiátricas, especialmente a internação, são contestadas, por influência do movimento antipsiquiátrico (Berlim et al, 2003), é importante a constatação de que vários colegas de internação de Lima Barreto não se encontravam reclusos sem que houvesse uma razão humanitária ou terapêutica para tal. Assim, as internações não eram simplesmente um instrumento de "exclusão que reinava absoluta sobre qualquer objetivo de recuperação e/ou integração", como afirmam Engel (2001) e muitos antipsiquiatras. Em relação ao aspecto supostamente libertador da loucura, que seria um "veículo de crescimento pessoal" (Laing, 1967), a leitura atenta de $O$ cemitério dos vivos deixa clara a inadequação desta visão quando se tem a experiência de viver próximo do adoecimento mental.

Ainda no campo da antipsiquiatria, é interessante discutir sobre o "mito da doença mental", tal como apresentado por Thomas Szasz, psicanalista que é um dos ícones da antipsiquiatria norte-americana. Segundo esse autor (1960), as "doenças mentais não são nada além de imposições fraudulentas perpetradas por psiquiatras cuja intenção central é a de preservar seus status profissionais". Em todo O cemitério dos vivos, Lima Barreto chama atenção para o caráter de existência da loucura, não o associando a priori aos psiquiatras. Outro elemento presente na obra do escritor é o desejo de que surja uma cura para o sofrimento causado pelo adoecimento mental, que limita as possibilidades existenciais do indivíduo, trazendo sua inexorável deterioração.

Ao mesmo tempo em que atesta a existência de vários pacientes portadores de doença mental no manicômio, Lima Barreto fornece 
descrições bastante acuradas dos quadros psicopatológicos manifestados. Como exemplo, pode-se mencionar o paciente F.P., que se encontra em passagem transcrita na página 52 desta dissertação. Este apresenta os seguintes critérios diagnósticos para episódio maníaco, segundo o DSM-IVTR (2002): humor persistentemente expansivo ("É o mais barulhento e rixento da casa. Desde as cinco horas da manhã até às sete ou oito da noite, ri, vive a gritar, a berrar"), auto-estima inflada ou grandiosidade ("mania de grandeza", nas palavras do autor), redução da necessidade de sono ("uma agitação que não o faz dormir, nem deixa o seu guarda dormir") e agitação psicomotora. Tais critérios são suficientes, atualmente, para se fazer o diagnóstico de episódio maníaco. O estudo das manifestações psicopatológicas descritas por Lima Barreto pode ser uma ferramenta de ensino interessante para aqueles que estudam psiquiatria, como alunos de medicina e médicos residentes.

Por fim, é oportuno fazer referência ao modo como a relação de Lima Barreto com a psiquiatria foi vista pelo próprio e por pesquisadores de sua obra e vida. Luciana Hidalgo (2008), afirma na introdução de seu livro Literatura da urgência, Lima Barreto no domínio da loucura: "Perdoem-me, pois, os excessos, mas ao acompanhar o escritor do indizível, um dos grandes nomes da literatura brasileira e sua escrita de percalços, sobretudo no domínio da loucura, não pude ignorar o caráter épico deste heroísmo". A própria autora admite, pouco antes, que recebeu uma crítica de uma professora que apontou sua "tendência a heroicizar Lima Barreto". A postura de considerar ex-internos de hospitais psiquiátricos vítimas, heróis ou 
"sobreviventes" é comum (Rissmiler, 2006). Esse último termo é aplicado atualmente por sua associação aos sobreviventes do holocausto. Vendo o paciente psiquiátrico dessa forma, o leitor passa a ter uma visão direcionada e parcial, ou preconceituosa em relação à psiquiatria. Assim, torna-se necessário um afastamento afetivo, que nem sempre é possível. Nessas situações, a leitura de obra literária, no calor afetivo, pode trazer mais confusão do que esclarecimento com relação a determinado tema (Beveridge, 2003).

A própria ambigüidade de Lima Barreto com relação à prática psiquiátrica é reflexo de conflitos e de posicionamentos que nem sempre são justificados por fatos empíricos. O preconceito que o autor possuía fica bastante claro quando ele associa a psiquiatria ao positivismo. Desse modo, a crítica à psiquiatria pode ser entendida como deslocamento de uma crítica maior ao sistema positivista. Em certos momentos, ao se dar conta da necessidade de ser cuidado e das qualidades de alguns médicos e enfermeiros, sente-se impelido a rever a sua posição. Nota-se em sua obra certa tendência a ver-se como herói ou como vítima da psiquiatria, mas tal visão é relacionada à sociedade como um todo que ele enxergava como racista; não sem razão, já que a escravidão foi abolida depois que ele já havia nascido.

O ressentimento do autor quanto ao tratamento que recebia da sociedade por conta de sua condição racial fica evidente na seguinte anotação do Diário Íntimo, datada de seis de novembro (o ano não é fornecido): 
Na estação, passeava como que me desafiando o C.J. (puto, ladrão e burro) com a esposa ao lado. O idiota tocou-me na tecla sensível, não há negá-lo. Ele dizia com certeza:

— Vê, "seu negro", você me pode vencer nos concursos, mas nas mulheres, não. Poderás arranjar uma, mesmo branca como a minha, mas não desse talhe aristocrático.

Suportei o desafio e mirei-lhe a mulher de alto a baixo e, dentro de alguns anos, espero encontrar-me com ela em alguma casa de alugar cômodos por hora. (p.1221)

\subsection{2- Relatos ficcionais da doença mental: Recordações do escrivão Isaías Caminha, Triste fim de Policarpo Quaresma e Clara dos Anjos}

Em Recordações do escrivão Isaías Caminha e Triste fim de Policarpo Quaresma, as obras iniciais de Lima Barreto, observam-se duas características principais dos transtornos mentais apresentados pelos personagens: eles são apresentados de forma ora idealizada, ora caricatural. Em ambos os casos, o adoecimento mental serve como uma defesa que leva o indivíduo para fora da realidade, já que esta seria insuportável por conta de todos os problemas e mazelas sociais enfrentadas na época. Assim, existiria certa virtude na condição de louco.

Talvez o personagem mais característico dessa concepção seja o major Policarpo Quaresma. Diante das situações que ele protagoniza, 
claramente absurdas aos olhos do outro, fica evidente sua comicidade. A esse propósito, é interessante a relação que pode ser estabelecida com o conceito de carnavalização e de grotesco, proposto por Mikhail Bakhtin.

Para Bakhtin, as representações carnavalizadas são referência importante para a literatura ocidental e têm em comum o fato de provocar o riso, que por sua vez leva a uma relativização da verdade e de concepções dominantes do mundo; ao ridicularizar tudo o que é referido como imutável e transcendente, o Carnaval traz a celebração da renovação do mundo (Soerensen, 2008). Segundo a mesma autora, "o espetáculo carnavalesco sem atores, sem palco, sem diretor - derruba as barreiras hierárquicas, sociais, ideológicas, de idade e de sexo. Representa a liberdade, o extravasamento; é um mundo às avessas no qual se abolem todas as abscissas entre os homens para substituí-las por uma atitude carnavalesca especial: um contato livre e familiar entre as pessoas."

Outra característica da representação carnavalizada é o uso das máscaras. A esse propósito, Bakhtin (2008) afirma: "É o motivo mais complexo, mais carregado de sentido da cultura popular. A máscara traduz a alegria das alternâncias e das reencarnações, a alegre relatividade, a alegre negação da identidade e do sentido único (...); a máscara é a expressão das violações das fronteiras naturais, da ridicularização (...)." O episódio em que Policarpo Quaresma encena o Tangolomango, na tentativa de resgatar elementos do folclore brasileiro, é bastante representativo da carnavalização. 
Dentro da visão bakhtiniana, Policarpo Quaresma pode ser tomado como um personagem grotesco, na medida em que subverte a realidade de seus contemporâneos. A loucura, para Bakhtin, é característica de qualquer grotesco, e acaba por tornar-se inofensiva e alegre, em vez de terrível e atemorizadora, através do uso dessa abordagem, que "liberta da falsa verdade desse mundo e permite a contemplação com um olhar liberto dessa verdade."

Dessa maneira, o uso da carnavalização da loucura, tão presente na obra inicial de Lima Barreto, pode ser entendido como uma tentativa de vê-la de uma forma menos ameaçadora. A obra literária cumpre aqui uma função de sublimação. Isso é compreensível tendo em vista que na época em que foi escrito Triste fim de Policarpo Quaresma, o autor já sofria com a doença do pai.

A idealização da doença mental que ocorre em outros personagens deve ser interpretada também no contexto de vida do autor. Tendo em vista as características psicológicas do mesmo, que possuía uma sensação de ser excluído pela elite da sociedade, a loucura adquire o tom de fuga de uma realidade ruim e por vezes insuportável. Possivelmente quando a sublimação de seus sentimentos pela arte não foi suficiente, Lima Barreto caiu no vício por álcool.

Em contraste a esses aspectos de como a alienação mental é mostrada na fase inicial da obra de Lima Barreto, em suas últimas obras a mesma aparece de forma mais realista e naturalista. Quanto aos relatos de 
doença mental presentes em Clara dos Anjos, é interessante observar que ela é decorrente do vício em bebidas alcoólicas, tanto em Leonardo Flores como em Meneses. Em ambos os personagens, o leitor se depara com a decadência e com o destino trágico dos personagens: a morte e a internação no manicômio. Aqui, a doença passa a mostrar sua face mais sombria, deixando de ser atribuído a ela algum componente positivo. Nota-se aqui evidente referência à biografia do autor do romance, que na época vivia em constante estado de degradação.

\section{2- As trajetórias dos protagonistas barretianos}

Para abordar o tema do rumo que os personagens tomam dentro de uma trama, recorrer-se-á ao conceito de cronotopo, estabelecido por Bakhtin. Em Questões de literatura e estética, esse autor conceitua os cronotopos da seguinte forma: "são os elementos temporais e espaciais que constroem os acontecimentos de uma obra, que trazem concretude a ela" (Bakhtin, 2002). Silva (2008) complementa essa definição, afirmando que os cronotopos são o tempo e os lugares que influenciam as ações das personagens e impulsionam o enredo.

Ao enumerar os tipos de cronotopos, Bakhtin dá destaque a dois: 0 presente no "romance de aventura e provação" e no "romance de aventuras de costumes". No primeiro, "o tempo das aventuras vivido pelo protagonista ou herói é um tempo à parte do curso normal da vida; enquanto tenta livrarse das maldições divinas, de perseguições comandadas pelo acaso ou pelo 
destino, o personagem não se transforma internamente. Nesse tempo da aventura, o homem é passivo e imutável." (ibid., pg. 31). Já nos romances de aventuras ou de costumes, "há uma relação cronotópica diferente, pois as aventuras vividas pelo herói se incorporam à sua biografia (...), alterando-a. Neste tipo de romance é comum ocorrer a metamorfose do herói, ou seja, a transformação do homem em outro ser, o que implica a reflexão sobre a identidade do indivíduo, além de alteração na forma de pensar da personagem e revelação de aspectos seus nunca antes vistos.” (ibid., p. 32)

Sob a perspectiva do conceito de cronotopo, pode-se afirmar que os protagonistas dos romances iniciais de Lima Barreto se aproximam mais daquele presente no romance de aventura e provação, ao passo que nos romances finais está mais presente o cronotopo de romance de aventura ou de costumes.

Tanto Isaías Caminha como Policarpo Quaresma passam por várias situações difíceis e provações. Isaías tenta conseguir um lugar na sociedade carioca racista do início do século XX e no fim consegue uma colocação. Ao final desse processo, encontra-se transformado, tendo adquirido uma maior compreensão dos mecanismos que regulam as relações sociais e abandonado sua concepção ingênua da vida. Para que isso tenha acontecido, vivenciou inúmeros conflitos psicológicos e sofrimentos. Policarpo Quaresma, por sua vez, apresenta durante quase todo o enredo convicções patrióticas plenas e tenta colocá-las em prática de diversas maneiras: propondo a adoção do tupi-guarani como língua oficial do Brasil, promovendo o folclore, cultivando aquela que ele acreditava ser a melhor 
terra do mundo e alistando-se nas Forças Armadas para combater a Revolta da Armada. Após inúmeras decepções ele é forçado, no entanto, a rever suas posições, adquirindo um tom amargo diante da vida e da realidade: "a sua vida era uma decepção, uma série, melhor, um encadeamento de decepções." Por fim, morre como mártir, incompreendido e por um país que não o merece.

Em Clara dos Anjos, por outro lado, a protagonista não passa por transformações semelhantes àquelas vivenciadas pelos personagens anteriormente comentados. Como analisa Sergio Buarque de Holanda (1996), "o romancista procurou fazer de sua personagem uma figura apagada, de natureza amorfa e pastosa, como se nela quisesse resumir a fatalidade que persegue tantas criaturas de sua casta (...). E Clara dos Anjos torna-se, assim, menos uma personagem do que um argumento vivo e um elemento para a denúncia." Percebe-se aqui como o crítico literário destaca a natureza passiva de Clara, que não passa de um joguete nas mãos do destino, sem capacidade de incorporar suas experiências em novas atitudes diante da vida. O autor assume, então, uma concepção fatalista do destino das pessoas, que seria determinado por fatores sociais. Essa visão é diferente daquela expressa em Recordações do escrivão Isaías Caminha, em que havia possibilidade de mudança no herói, apesar das intempéries. Considerando-se a biografia de Lima Barreto, tal mudança pode estar associada a uma visão mais pessimista do autor, que estava no final de sua vida e em franco declínio físico. 
Pelo fato de O cemitério dos vivos ser uma obra inacabada, não é possível fazer considerações mais amplas quanto ao percurso do protagonista Vicente Mascarenhas, tomando sua linha existencial como um todo. No entanto, pode-se constatar que o fatalismo está presente em diversas passagens, sendo feitas menções ao determinismo biológico e social em vários trechos da obra.

\section{3- As análises linguísticas das obras com o uso da ferramenta computacional}

Foi verificado que existe uma diminuição do índice type-token comparando-se as obras iniciais (Recordações do escrivão Isaías Caminha e Triste fim de Policarpo Quaresma) e a final, Clara dos Anjos, a partir de 30.000 tokens. Antes desse valor, não existe uma distinção clara no comportamento das curvas relacionadas às três obras de Lima Barreto. Esse achado é interessante, já que sugere que a comparação dos índices typetoken entre produções escritas de um mesmo indivíduo só pode ser realizada entre corpora grandes, do tamanho de um pequeno romance.

A queda do índice type-token em Clara dos Anjos pode ter correlação com declínio cognitivo leve do autor. Sabe-se que na época em que esse romance foi escrito, no final da vida de Lima Barreto, este apresentava sinais evidentes de decadência física em virtude do alcoolismo, tendo apresentado inclusive manifestações de desnutrição e de delirium tremens. A gravidade do quadro de alcoolismo está, assim, documentada. 
Quanto a Clara dos Anjos, foi visto pela crítica como uma obra fraca, segundo Francisco de Assis Barbosa. Sendo assim, é pertinente supor que efeitos crônicos da dependência alcoólica tenham interferido na cognição do autor e, por consequência, na execução do romance, apesar de não terem sido descritos sinais de demência em Lima Barreto por seu biógrafo (ele é descrito como uma pessoa intelectualmente ativa até o final de sua vida).

O único estudo encontrado na literatura médica que relacionou queda de índice type-token com declínio cognitivo expresso na obra de um autor, o de Garrard et al (2005), apontou sinais de demência de Alzheimer subclínica expressos no último livro de Iris Murdoch. No entanto, em virtude de algumas dificuldades metodológicas na execução do presente trabalho, é dificultado o estabelecimento de correlação entre queda do índice type-token na obra de Lima Barreto e declínio cognitivo associado a alcoolismo. Uma das principais é o fato de que esse escritor não sofria apenas do quadro de alcoolismo, mas também de depressão, que pode levar a alterações neuropsicológicas muito semelhantes àquelas encontradas em quadros demenciais (Raskind, 1998). Outro problema relaciona-se à edição das obras. Diferentemente do estudo com a obra de Iris Murdoch, em que havia a certeza de que as obras analisadas não haviam recebido interferência no processo de edição, não se pode afirmar a mesma coisa com relação aos romances de Lima Barreto.

Uma possível aplicação do índice type-token, na clínica, seria o rastreamento de demência, em sua fase inicial. Para que isso ocorra, no entanto, é importante que sejam realizados estudos que mostrem o 
comportamento do índice em corpora extraídos dos discursos de pacientes, já que os achados em textos escritos não são facilmente extrapoláveis para a linguagem oral. Como afirma Chafe (1994), os textos escritos não refletem a espontaneidade presente nos relatos orais, e podem não ser a melhor fonte para se estudar alterações de linguagem presentes no autor do discurso. Uma limitação para o uso clínico da técnica e que é sugerida nesta dissertação é o fato de alterações estatísticas no índice type-token terem sido constatadas apenas em corpora grandes, o que poderia inviabilizar sua aplicação no consultório.

Quanto à confusão entre alterações nos índices type-token produzidas por demência ou por quadros depressivos, uma ferramenta que poderá ser útil na diferenciação é a determinação de palavras-chave (keywords). Na obra de Lima Barreto, esse recurso, através da comparação com um corpus literário de referência formado por textos de autores contemporâneos a ele, mostrou-se capaz de identificar um tema bastante presente em sua obra: a doença mental representada na palavra mania, que no tempo desse autor era usada para denominar loucura de maneira geral (Teixeira, 2005). Na aplicação em pacientes, poder-se-á formular uma hipótese de depressão, e não de demência, nos casos em que forem encontradas muitas palavras-chave relacionadas a termos negativos ou depreciativos. A análise dos contextos em que os termos ocorrem, com a ferramenta concord, pode, por sua vez, permitir uma melhor compreensão do modo como esses termos se articulam ao restante do discurso. 
Além do estudo de Garrard et al, não foram encontrados outros na base de dados Pubmed que procurem relacionar índice type-token com demência. Por outro lado, há trabalhos que mostram queda desse índice em pacientes com esquizofrenia, o que ilustra o fato de que eles possuem menor variabilidade do léxico (Adewuya e Adewuya, 2008; Congzhou, 2006; Linscott, 2005).

Cumpre mencionar que, comparando-se os índices type-token das obras de Lima Barreto com os dos autores que fizeram parte do Corpus Referência, observou-se uma variação muito grande das obras individualmente, o que mostra que o estilo pessoal tem muita influência nos valores encontrados. Por exemplo, Os sertões de Euclides da Cunha e Dom Casmurro de Machado de Assis apresentaram grande diferença dos índices type-token, sendo que Os sertões teve maior diversidade lexical. Isso não significa, evidentemente, que uma obra seja melhor que a outra. Assim, ao se comparar os discursos de pacientes na clínica, devem-se procurar valores de referência confiáveis, sendo necessários estudos adicionais para que possam ser identificadas as variáveis que influenciam nesses valores. 


\section{7- CONCLUSÕES}

1- A obra de Lima Barreto, especialmente $O$ cemitério dos vivos, é uma fonte representativa para aqueles que estudam história da psiquiatria brasileira do início do século $\mathrm{XX}$ e fornece elementos diversos daqueles presentes em vários estudos, principalmente ligados a ideologias críticas à psiquiatria;

2- As obras ficcionais desse autor fazem várias referências a personagens que apresentam quadro de doença mental. As características da representação dos transtornos mentais são diferentes nas obras iniciais e finais, provavelmente refletindo elementos biográficos e psicológicos do autor;

3- A última obra de Lima Barreto apresenta diversidade lexical menor que as iniciais, apontada através de um menor índice type-token. Esse achado pode ter relação com declínio cognitivo secundário ao alcoolismo;

4- A extrapolação do uso da ferramenta computacional usada na pesquisa para o rastreamento de alterações cognitivas na população depende da validação do método em indivíduos no contexto clínico. 


\section{8- REFERÊNCIAS}

Adewuya AO, Adewuya AO. Flexibility and variability in lexicon usage among Yoruba-speaking Nigerian outpatients with schizophrenia: a controlled study. Psychopathology. 2008; 41(5): 294-9.

Andrade CD. Entre Machado e Lima Barreto. Jornal do Brasil, Rio de Janeiro, 14 maio 1981.

Andreasen NJ, Powers PS. Creativity and psychosis, an examination of conceptual style. Arch Gen Psychiatry, 1975; 32 (1): 70-3.

Creativity and mental illness: prevalence rates in writers and their first-degree relatives. Am J Psychiatry. 1987; 144 (10): 1288-92.

\& Pfohl B Linguistic Analysis of Speech in Affective Disorders. Arch Gen Psychiatry. 1976; 33: 1361-67.

Ataíde T. Lima Barreto. O jornal, Rio de Janeiro, 26 nov 1922.

Bakhtin M. Cultura popular na idade média e no renascimento- o contexto de François Rabelais. Brasília: Hucitec; 1987.

Estética da criação verbal. São Paulo: Martins Fontes; 2003. 
Questões de literatura e estética: a teoria do romance. São Paulo: Unesp; 1990.

Baltieri DA. Utilização do acamprosato no tratamento de dependentes de álcool [dissertação]. São Paulo: Universidade de São Paulo; 2002.

Barbosa FA. A vida de Lima Barreto, 9a. ed. Rio de Janeiro: José Olympio, 2003.

Lima Barreto, Precursor do romance brasileiro. Publicado em Boletim Bibliográfico, Biblioteca Mário de Andrade, v. 42, n.3, jul./set. P. 941.

Berlim MT. Notes on antipsychiatry. Eur Arch Clin Neurosci. 2003; 253: 61-7.

Beveridge A. Should psychiatrists read fiction? British Journal of Psychiatry. 2003; 182:385-387.

--------.-. "Is everyone mad?" The depiction of mental disturbance in the work of Dostoyevsky. Advances in Psychiatric Treatment. 2009; 15:32-39.

Blanc C. Por dentro do Triste Fim de Policarpo Quaresma. In: Triste Fim de Policarpo Quaresma. Editora Saraiva: São Paulo; 2007. 
Brody H. Stories of Sickness. Newhaven, CT: Yale University Press; 1987.

Brunke M, Gilbert M. Alcohol and creative writing. Psychol Rep. 1992; 71 (2): 651-8.

Chafe W. Discourse, consciousness and time: the flow and displacement of conscious experience in speaking and writing. Chicago and London: University of Chicago Press; 1994.

Congzhou, $\mathrm{H}$. Using text analysis software in schizophrenia research. CASPR Research Report 2006-2.

Couto, R. Carta a Francisco de Assis Barbosa. Belgrado, 20/03/1950.

Critchley EMR. Linguistics in a Neuropsychiatric Frame. A look at the dialogue of brain and mind. British Journal of Psychiatry, 1994; 165, 573-6.

Cunha PJ, Novaes MA. Avaliação neurocognitiva no abuso e e dependência do álcool: implicações para o tratamento. Rev. Bras. Psiq. 2004; 26 (supl. 1): 23-27.

Dalgalarrondo P. Psicopatologia e semiologia dos transtornos mentais, $2^{\mathrm{a}}$ edição. São Paulo: Artmed; 2008. 
Davis WM. Premature mortality among prominent American authors noted for alcohol abuse. Drug Alcohol Depend. 1986; 18(2): 133-8.

Day E, Smith I. Literary and biographical perspectives on substance use. Advances in Psychiatric Treatment. 2002; 9: 62-8.

Engel MG. Os delirious da razão- médicos, loucos e hospícios (Rio de Janeiro, 1830-1930). Rio de Janeiro: Editora Fiocruz; 2001.

Evans M, Sweeney K. The Human Side of Medicine. Occasional paper OP76. London : Royal College of General Practitioners; 1998.

Figueroa CG. Virginia Woolf : enfermedad mental y creatividad artística. Rev Méd Chile. 2005; 133: 1381-1388.

Garrard P, Maloney LM, Hodges JR, Paterson K. The effects of very early Alzheimer's disease on the characteristics of writing by a renowned author. Brain. 2005; 128: 250-60.

Geddes J. Editorial. Evidence-based Practice in mental health. 1998; 1: 4-5

Gersie, A. Reflections on Therapeutic Storymaking: The Use of Stories in Groups. London: Jessica Kingsley; 1997. 
Green J. Psychiatry and the arts: new interfaces? Advances in psychiatric treatment. 2008; 14:163-166

Greenhalgh T, Hurwitz B. Why study narrative. In Narrative Based Medicine London: BMJ Books; 1998.

Guimarães LB. Pedagogias literárias: o sertão amazônico como deserto. UNIVALI, 2008. 1: 1-13.

Hidalgo L. Literatura da urgência: Lima Barreto no domínio da loucura. São Paulo: Annablume; 2008.

Hunter KM. Doctor's Stories: The Narrative Structure of Medical Knowledge. Princeton, CA: Princeton University Press; 1991.

Holanda SB. Clara dos Anjos. In: Holanda SB. Livro dos prefácios. São Paulo: Companhia das Letras; 1996. p. 384-94.

Jamison KR. Touched with fire: manic-depressive illness and the artistic temperament. New York: Free Press Paperbacks; 1993.

Laing RD. The politics of experience. London, Penguin; 1967.

Lester D. Premature mortality associated with alcoholism and suicide in American writers. Percept Mot Skills, 73 (1): 162; 1991. 
Lima Barreto: prosa seleta. Organização: Eliane Vasconcellos. Rio de Janeiro: Nova Aguilar, 2001.

Linscott RJ. Thought disorder, pragmatic language impairment, and generalized cognitive decline in schizophrenia. Schizophr res. 2005. 15; 75(2-3): 225-32.

Lopes JL. A psiquiatria de Machado de Assis. Rio de Janeiro: Livraria Agir Editora; 1974.

Lucas F. Confissões e fundamentos de Lima Barreto. In: Barreto L. O Cemitério dos vivos. São Paulo: Edições Biblioteca Nacional; 2004.

Ludwig AM. Mental illness and creative activity in female writers. Am J Psychiatry. 1994; 151 (11): 1650-6.

Alcohol input and creative output. $\mathrm{Br} \mathrm{J}$ Addict. 1990; 85 (7): 953-63.

Manual diagnóstico e estatístico de transtornos mentais - DSM-IV-TR. Porto Alegre: Artmed; 2002.

Martelotta ME. Manual de linguistica. São Paulo: Editora Contexto; 2008. 
Nash C. The use of storytelling in the sciences, Philosophy and Literature. London: Routledge; 1994.

Oda AMGR, Dalgalarrondo P. Apresentação. In: Pinel P. Tratado médicofilosófico sobre a alienação mental ou a mania. Porto Alegre: Editora da UFRGS; 2007. p.15-44.

Oyebode F. Editorial: literature and psychiatry. Advances in Psychiatric Treatment. 2002; 8:397-398.

Paim I. Tratado de clínica psiquiátrica. 3ª ed. São Paulo: EPU; 2001.

Pereira LM. Prefácio. In: Barreto, Lima. Clara dos Anjos. Rio de Janeiro: Mérito, 1948

Pesavento SJ. História \& literatura: uma velha-nova história. Nuevo Mundo Mundos Nuevos; 6; 2006

Pessotti I. O século dos manicômios. Rio de Janeiro: Editora 34; 1996.

Pinel P. Tratado médico-filosófico sobre a alienação mental ou a mania. Porto Alegre: Editora da UFRGS; 2007.

Post F. Verbal creativity, depression and alcoholism. An investigation of one hundred American and British writers. Br J Psychiatry. 1996; 168 (5): 545-55 
Creativity and psychopathology. A study of 291 world-famous men. Br J Psychiatry. 1994; 165 (2): 22-34.

Postel J, Quétel C. Historia de la psiquiatria. México DF: Fondo de Cultura Económica; 1987.

Raskind MA. The clinical interface of depression and dementia. J Clin Psychiatry. 1998; 59 suppl 10. p. 9-12.

Rissmiller DJ, Rissmiller JH. Evolution of the antipsychiatry movement into mental health consumerism. Psychiatric services. 2006: 57 (6). p. 863-6.

Roberts GA. Narrative and severe mental illness: what place do stories have in an evidence-based world? Advances in Psychiatric Treatment. 2000; 6:432-441.

Sardinha TB. Lingüística de Corpus. Barueri: Manole; 2004.

Shorter E. A history of psychiatry: from the era of the asylum to the age of prozac. New York: John Wiley; 1997.

Silva Al. Tempo, espaço e autoconsciência: a construção da identidade em Ensaio sobre a cegueira [tese]. São Paulo: Universidade de São Paulo; 2008. 
Snow CP. The two cultures and the scientific revolution. Cambridge: Cambridge University Press; 1959.

Soerensen C. O mez da grippe: a Babel carnavalizada [dissertação]. Curitiba: Universidade Federal do Paraná; 2008.

Strauss J. The person with schizophrenia as a person. British Journal of Psychiatry. 1994; 164 (suppl. 23): 103-107.

Sullivan EV, Rosenbloom, MJ, Pfefferbaum A. Pattern of motor and cognitive deficits in detoxified alcoholic men. Alcohol Clin Exp Res 24(5): 611-621; 2000.

Szasz T. The myth of mental illness. New York: Hoeber-Harper; 1960.

Szatmari P. Evidence-based child psychiatry and the two solitudes. Evidence-based mental health. 1999; 2:6-7

Teixeira CM. Narração, dialogismo e carnavalização: uma leitura de 'A hora da estrela', de Clarice Lispector [tese]. São Paulo: Universidade de São Paulo; 2007.

Teixeira I. Policarpo Quaresma como caricatura de uma idéia de Brasil. In: Barreto, Lima. Triste fim de Policarpo Quaresma. Cotia: Ateliê Cultural; 2004. p. 9-38. 
Tezza C. Sobre o autor e o herói- um roteiro de leitura. In: Diálogos com Bakhtin. Curitiba: Editora UFPR; 2007. p. 231-56.

Thomas P, Fraser W. Linguistics, Human Communication and Psychiatry. $\mathrm{Br}$ J Psychiatry. 1994; 165: 585-92.

Vasconcellos E. Nota editorial. In: Lima Barreto Prosa Seleta. Editora Nova Aguilar: Rio de Janeiro; 2001.

Vieira RMTV. Prejuízos neurocognitivos na dependência alcoólica: um estudo de caso. Rev. Psiq. Clín. 2007; 34(5):246-250.

Wolpert L. Malignant Sadness. London: Faber \& Faber; 1999.

Zoppe E. Ensinando psicodinâmica para residentes de psiquiatria [dissertação]. São Paulo: Universidade de São Paulo; 2007. 